\title{
Meta-analysis of the relation between European and American smokeless tobacco and oral cancer Rolf Weitkunat*1, Edward Sanders ${ }^{1}$ and Peter N Lee ${ }^{2}$
}

Address: ${ }^{1}$ PMI Research \& Development, Philip Morris Products S.A., Neuchâtel, Switzerland and ${ }^{2}$ P.N. Lee Statistics and Computing Ltd, Surrey, UK

Email: Rolf Weitkunat* - Rolf.Weitkunat@pmintl.com; Edward Sanders - Edward.Sanders@pmintl.com; Peter N Lee - PeterLee@pnlee.co.uk

* Corresponding author

Published: 15 November 2007

BMC Public Health 2007, 7:334 doi:10.1 I86/I47|-2458-7-334

This article is available from: http://www.biomedcentral.com//47/-2458/7/334

(c) 2007 Weitkunat et al; licensee BioMed Central Ltd.

This is an Open Access article distributed under the terms of the Creative Commons Attribution License (http://creativecommons.org/licenses/by/2.0), which permits unrestricted use, distribution, and reproduction in any medium, provided the original work is properly cited.
Received: 4 October 2006

Accepted: 15 November 2007

\begin{abstract}
Background: Smokeless tobacco is often referred to as a major contributor to oral cancer. In some regions, especially Southeast Asia, the risk is difficult to quantify due to the variety of products, compositions (including non-tobacco ingredients) and usage practices involved. In Western populations, the evidence of an increased risk in smokeless tobacco users seems unclear, previous reviews having reached somewhat differing conclusions. We report a detailed quantitative review of the evidence in American and European smokeless tobacco users, and compare our findings with previous reviews and meta-analyses.

Methods: Following literature review a meta-analysis was conducted of 32 epidemiological studies published between 1920 and 2005 including tests for homogeneity and publication bias.

Results: Based on 38 heterogeneous study-specific estimates of the odds ratio or relative risk for smokeless tobacco use, the random-effects estimate was I.87 (95\% confidence interval I.40-2.48). The increase was mainly evident in studies conducted before 1980. No increase was seen in studies in Scandinavia. Restricting attention to the seven estimates adjusted for smoking and alcohol eliminated both heterogeneity and excess risk (I.02; 0.82-1.28). Estimates also varied by sex (higher in females) and by study design (higher in case-control studies with hospital controls) but more clearly in studies where estimates were unadjusted, even for age. The pattern of estimates suggests some publication bias. Based on limited data specific to never smokers, the random-effects estimate was I.94 (0.88-4.28), the eight individual estimates being heterogeneous and based on few exposed cases.
\end{abstract}

Conclusion: Smokeless tobacco, as used in America or Europe, carries at most a minor increased risk of oral cancer. However, elevated risks in specific populations or from specific products cannot definitely be excluded.

\section{Background}

Oral cancer, histologically most frequently squamous-cell carcinoma, includes malignant neoplasms of the lip, tongue, palate, gum, piriform sinus, floor of the mouth, pharynx, tonsils, salivary glands and unspecified parts of the mouth [1]. It is the eighth and $14^{\text {th }}$ most incident cancer worldwide in men and women, respectively [2]. Agestandardised mortality rates (per 100,000 per year) differ 
regionally, ranging (in 2001) from 2.4 in Sweden to 21.2 in Hungary. Trends differ also, with, in the past two decades, decreases in the US, Finland and Sweden, and increases in Hungary, the Czech Republic, Germany and Norway $[3,4]$. US mortality rates are higher in blacks than whites, and prevalence is greater in areas with a high proportion of Asians [5].

Among specific risk factors commonly discussed are alcohol, solar radiation, genetic predisposition, and tobacco (smoking and smokeless). Smoking has been estimated to pose twice as high a risk of oral cancer as does smokeless tobacco use [6]. Except for the exact magnitude of the risk difference, this is rarely questioned, and usually attributed to the lack of combustion products from smokeless tobacco [7]. Smokeless tobacco products are traditionally classified as snuff or chewing tobacco [8]. In Europe and North America usage is mostly oral, while nasal use of finely ground "dry snuff" has become rare [9]. In the US, finely cut "moist snuff" or chewing tobacco is held (or in the case of the latter chewed) in the gingival buccal area. In Scandinavia snuff (or snus in Sweden) is generally placed under the upper or lower lip.

Oral tobacco has long been referred to as a major contributor to oral cancer incidence. In line with International Agency for Research on Cancer [IARC] monograph 37 [10], the US Surgeon General [11] concluded in 1986 that "the association between smokeless tobacco use and cancer is strongest for cancers of the oral cavity" and that "evidence for an association between smokeless tobacco use and cancers outside the oral cavity in humans is sparse." The conclusion for oral cancer was based on only a few, mainly quite small studies that provided quantitative data.

Later Gross et al. [12] meta-analysed 12 US studies conducted between 1952 and 1993. They computed a random-effects relative risk of 1.74 (95\% confidence interval [CI]: 1.32 to 2.31 ) and concluded that "a relative risk $<2.0$ may be considered to represent a weak association because of the biases and confounders that tend to affect observational studies." While the individual relative risk [RR] estimates ranged from 0.99 to 4.44 , those in 12 studies in Southeast Asia ranged from 2.2 to 39.19, corresponding to an overall estimate of 8.94 (95\% CI: 5.26-15.18). Gross et al. concluded that "the studies in Southeast Asia suggest a strong relationship between the risk of oral cancer and the use of chewing tobacco. The tobacco chewed in these countries was often mixed with some other substances, such as betel quid and areca nut. It is still unclear whether it is the tobacco or the substance added [that] plays the major role." The authors also reported estimates from four studies in other regions, two in Europe and two in Latin America. These ranged from
0.67 to 1.40 , more resembling the US than the Southeast Asian findings.

In 1996 Pershagen [9] published a wide-ranging review on exposure and health aspects of smokeless tobacco. With respect to oral cancer he stated that "methodological limitations in the studies make it difficult to interpret the findings." Nevertheless, based on six case-control studies from Sweden and the US, and with particular emphasis on the study of Winn et al. [13], which he considered to be the most conclusive, Pershagen inferred that "habitual use of oral tobacco can increase the risk of oral cancer." He cited an odds ratio [OR] of 4.2 for the Winn et al. study. However, this estimate refers to only a subgroup (white nonsmoking women). In contrast, the estimate based on all the available data was lower at 2.7 (1.8-3.9).

In a toxicological and epidemiological assessment of the health risks of snuff dipping, Nilsson [14] concluded that "although a small risk cannot be excluded, the use of smokeless tobacco products low in TSNA which now are available on the market entails a risk that at any rate is more than 10 times lower than that associated with active smoking." He pinpointed "a wide discrepancy" between the estimated cancer risk found in studies conducted in Sweden and the US. The US data were drawn mostly from the Winn et al. study [13]. For Sweden Nilsson concluded that although about " $20 \%$ of all grown-up Swedish males use moist snuff, it has not been possible to detect any significant increase in the incidence of cancer of the oral cavity or pharynx - the prevalence of which by international standards remains low in this country." At the ecological level the situation is similar in the US. West Virginia has the highest consumption of smokeless tobacco of all US states, but below average oral cancer incidence rates [15].

Rodu and Cole [16] conducted a meta-analysis on smokeless tobacco use and upper respiratory tract cancer based on 21 publications. Although the available data about tobacco type are sparse and ambiguous in some reports, the authors attempted separate analyses. For oral and pharyngeal cancer they estimated a relative risk of 1.1 (0.8-1.6) for chewing tobacco, $0.7(0.4-1.2)$ for moist snuff, 4.0 (2.7-5.9) for dry snuff and 1.5 (1.1-2.0) for unspecified smokeless tobacco use. They concluded that "the use of moist snuff and chewing tobacco imposes minimal risks for cancers of the oral cavity and other upper respiratory sites..."

Critchley and Unal [17] conducted a narrative literature review of studies with a total sample size of at least 500 participants, including studies in both Western and Southeast Asian countries. They concluded that the study of Winn et al. [13] "remains the strongest evidence for an association of ST use with oral cancers in the US, although 
it is limited to women and was carried out many years ago." They based this conclusion on the same OR estimate of 4.2 that Pershagen [9] cited. For Scandinavian studies the reviewers concluded that "although these findings are consistent with no effect, the studies do not have sufficient power to detect a moderately raised OR." Overall, according to Critchley and Unal, there exists "...a substantial risk of oral cancers in India" while for the US and Scandinavia "most recent studies...are not statistically significant, but moderate positive associations cannot be ruled out due to lack of power."

The information we examined suggests at most a minor increased risk of oral cancer associated with smokeless tobacco use in Western countries. Elsewhere, products used are likely to differ in toxicity, and their associated risk, especially in Southeast Asia, is difficult to quantify due to the variety of products, compositions (including non-tobacco ingredients) and usage practices involved. Our objective was to conduct a detailed analysis of published evidence on the association of American and European smokeless tobacco and oral cancer, and to calculate a pooled effect estimate. Compared with the reviews of Rodu and Cole [16] and Critchley and Unal [17] we aimed to include more studies, and carry out a more detailed quantitative analysis, including random-effects and fixed-effect meta-analyses and an investigation of heterogeneity.

\section{Methods}

\section{Study identification and selection}

RW identified reports from a systematic search, not limited by period or language, of MEDLINE, EMBASE, CANCERLIT and TOXLINE through March 2005. The main searches used combinations of the terms "smokeless tobacco", "chewing tobacco", "snuff", and "snus" for exposure, and "oral cancer" and "mouth neoplasms" for outcome. Specific oral cancer sites corresponding to ICD10 codes C00 to C14 [1] were also searched for. Further articles were identified from reference lists in individual papers and reviews.

All reports had to satisfy the following Inclusion criteria: published in peer reviewed journal or publicly available, based on research on humans, of cohort or case-control design, study location specified, any form of oral cancer as the outcome, and chewing tobacco, orally used moist snuff or unspecified smokeless tobacco as the exposure. They also had to satisfy the Exclusion criteria: sample included in a more complete or recent study, conducted in an Asian population, no control group, inappropriate design (case report, qualitative study or review/meta-analysis), insufficient power (less than five expected exposed cases), appropriate risk estimates and CIs not reported and cannot be computed from the available data.
Having completed this process, RW then compared the selected studies with those of a previous unpublished review conducted in 2002 by PNL based on MEDLINE, reference lists and reviews.

\section{Data extraction}

From each report details were abstracted relating to the study (design, period, region, population, sample selection, size, and matching criteria), the exposure (method of assessment, type of smokeless tobacco investigated, exposure doses and durations considered), the outcome (type and location of oral cancer and method of diagnosis), and issues relating to analysis (type of effect measure, analysis methods, stratification variables, and adjustment factors).

To avoid bias, it would be advantageous to restrict attention to estimates of effect size (OR or RR) and of precision (95\% CI) based on subjects who have never smoked. However, such results are rarely available, and are often based on very limited numbers of cases. Our main analyses are therefore based on estimates derived from the whole population, smokers and nonsmokers combined, except for studies where the only available results are specifically for smokers or for nonsmokers. However, estimates of effect size and precision specifically for never smokers were also extracted for an additional analysis (see the end of the results section).

Where possible, separate estimates were obtained for male and female subjects and for different types of smokeless tobacco; chewing, snuff or smokeless (unspecified or chewing/snuff). Estimates for ever exposure were preferred to estimates for current exposure. Adjusted estimates were preferred to crude estimates and where multiple adjusted estimates were available, that adjusted for the most potential confounding variables was used.

In many studies, the required estimates of effect size and precision were not given by the authors and had to be estimated. Crude estimates were derived from the relevant 2 $\times 2$ table using standard methods, with, where necessary, numbers estimated from proportions given numerically or graphically and/or combined over types of oral cancer or levels of exposure. Independent crude estimates were combined over strata by fixed-effect meta-analysis [18] to obtain estimates adjusted for the stratifying variables. Non-independent adjusted estimates were combined over exposure levels or types of oral cancer using a method that accounts for the correlation of estimates with a common baseline group [19-21]. In a few studies where information was available on chewing and on snuff but not on joint use, approximate estimates for combined smokeless use were obtained assuming that no-one used both products. 


\section{Meta-analysis}

For effect size estimate, the standard error of its logarithm was calculated from its reported or estimated CI, assuming that the effect size was log-normally distributed. The logarithms of the effect sizes and their corresponding standard errors formed the data points for fixed-effect and random-effects meta-analyses[18]. Separate sets of metaanalyses were carried out for chewing tobacco, for snuff and for overall smokeless tobacco use (both from studies where only estimates for unspecified use were available and from studies where the estimate was derived from the separate data for chewing tobacco and snuff). A fourth set of meta-analyses, referred to as "all" types in the tables, used the smokeless tobacco estimates where available and otherwise the estimates specifically for chewing tobacco or for snuff. Within each set, meta-analyses were carried out based on all the estimates, regardless of the extent of confounding adjustment, and on estimates that were unadjusted or adjusted for various combinations of smoking, alcohol, age and social status. For each analysis, within-group heterogeneity was assessed by the chisquared test of homogeneity [22] and by the $\mathrm{I}^{2}$ statistic [23].

For selected meta-analyses, a forest plot is shown. Each estimate is shown as a rectangle, with its area proportional to its weight. The $\mathrm{CI}$ is indicated by a horizontal line. The data are plotted on a logarithmic scale so that the estimate is centred in the CI. Also shown in the plot are the actual values of the estimate and its $\mathrm{CI}$ and weight. Results from a random effects meta-analysis are also shown. The combined estimate is presented as a diamond with the width corresponding to the $\mathrm{CI}$, and the estimate as the centre of the diamond.

For the "all" types set of estimates, sensitivity analyses were carried out by eliminating those estimates that were only for smokers or only for nonsmokers, and also by replacing those estimates that were calculated approximately assuming that there were no joint users of chewing tobacco and snuff by estimates for chewing tobacco in US studies and for snuff in Swedish studies. Heterogeneity was also investigated further, separately for estimates unadjusted for any factor and estimates adjusted for smoking. Subgroups were defined a priori by type of smokeless tobacco, sex, study design, study location, study period, and by whether or not the estimate was reported by the author or was derived by us. Between-subgroup heterogeneity was assessed by a chi-squared test [24]. To describe the contribution of the investigated subgroups further, the between-subgroup chi-squared was expressed as a percentage of the total chi-squared.
Additional meta-analyses were carried out for the set of estimates for smokeless tobacco use among never smokers.

Publication bias was assessed by a funnel plot, in which the logarithm of the effect size was plotted against its precision $[25,26]$.

\section{Results}

1313 potentially relevant studies were identified by the literature search, but only 63 appeared possibly of value from initial assessment. These underwent more detailed examination and 32 met the inclusion and exclusion criteria. Of the 31 studies that did not, ten were excluded due to insufficient quantitative information [14,27-35], five to lack of a control group [36-40], two to limited power[41,42], three to the outcome not being oral cancer [43-45], and three to non-Western smokeless tobacco [46$48]$. Two reports $[49,50]$ were letters commenting on studies already rejected for other reasons, and two were reviews [51,52]. Four publications [53-56] referred to studies which were more recently or more completely or adequately covered in other publications [13,57-59].

\section{Extracted data}

Table 1, sorted on publication year, gives details of the 29 case-control and three cohort studies considered in this analysis. The reports were published between 1920 and 2005. 25\% of the studies were published up to 1970 and $25 \%$ after 1994 . Most studies (no $=24$ ) were conducted in the USA, with three in Sweden (studies 19, 27, 29), and one each in Puerto Rico (study 7), the UK (study 9), Brazil (study 18), Denmark (study 26), and Norway (study 31).

Not all studies were primarily concerned with the relationship between smokeless tobacco and oral cancer. Consequently, study-specific inclusion and exclusion criteria varied, as did criteria for matching of controls. Of the 29 case-control studies, seven (studies 3, 10, 11, 14, 15, $25,28)$ selected controls without smoking-related diseases, five $(2,7,18,19,23)$ selected controls without any cancer or without oral and other specific cancers, nine ( 1 , $4,5,6,8,12,13,17,24)$ selected patient controls without oral cancer, and eight $(9,16,20,21,26,27,29,30)$ selected population controls essentially without restriction.

Table 2 shows the cancer sites considered in the 32 studies. The definitions of sites were often imprecisely stated, so the table must be regarded as an approximation.

Table 3 contains the main results (i.e. those for smokers and nonsmokers combined where possible) for the 32 studies. Further estimates relating to the site where the smokeless tobacco was held are given elsewhere[60]. Most 
דable I: Study overview (included studies).

\begin{tabular}{|c|c|c|c|c|c|c|c|c|}
\hline Study & $\begin{array}{l}\text { First author, year of } \\
\text { publication }\end{array}$ & Region & Study period ${ }^{\mathrm{a}}$ & Design $^{b}$ & Sex & $\begin{array}{c}\text { Case definition } \\
\text { (or at risk populationc) }\end{array}$ & $\begin{array}{c}\text { Controls } \\
\text { (or years of follow-up) }\end{array}$ & Matching factors ${ }^{e}$ \\
\hline I & Broders 1920 [74] & USA & up to 1920 & $\mathrm{CCH}$ & $M+F$ & NS & No lip cancer & NS \\
\hline 2 & Moore $1953[57]$ & USA & $1951-1952$ & $\mathrm{CCH}$ & M & $50+$ years & No cancer & NS \\
\hline 3 & Wynder $1957[58]$ & USA & up to 1957 & $\mathrm{CCH}$ & $M^{f}$ & NS & $\begin{array}{l}\text { Benign diseases, lymphoma, skin and gastrointestinal } \\
\text { cancer }\end{array}$ & Age, rel, ins, ses \\
\hline 4 & Peacock 1960 [93] & USA & 1952-1958 & $\mathrm{CCH}$ & $M+F$ & With data on tobacco habits & No oral cancer & Sex, race, ins \\
\hline 5 & Vogler $1962[62]$ & USA & 1956-1957 & $\mathrm{CCH}$ & $M+F$ & Incident and prevalent & No oral cancer & None \\
\hline 6 & Vincent 1963 [94] & USA & up to 1963 & $\mathrm{CCH}$ & $\mathrm{Mg}$ & Incident & Successive gastrointestinal patients & Age \\
\hline 7 & Martinez 1969 [95] & Puerto Rico & 1966 & $\mathrm{CCH} / \mathrm{P}$ & $M+F$ & Incident in 1966 & Patients without cancer and community controls & Age, sex \\
\hline 8 & Keller 1970 [75] & USA & $1958-1962$ & $\mathrm{CCH}$ & M & Discharged with complete records & No oral cancer & Age, hosp, time \\
\hline 9 & Browne $1977[96]$ & UK & |957-197| & $\mathrm{CCP}$ & $M+F$ & NS & Community controls & Age, sex, occ, area \\
\hline 10 & Williams 1977 [97] & USA & |969-197| & $\mathrm{CCH}$ & $M+F$ & Incident, Third National Cancer Survey & No tobacco- or alcohol-related cancers & None \\
\hline II & Wynder 1977 [98] & USA & $1969-1975$ & $\mathrm{CCH}$ & M & Histologically confirmed & No tobacco-related diseases & Age, race, area \\
\hline 12 & Westbrook 1980 [63] & USA & 1955-1975 & $\mathrm{CCH}$ & $\mathrm{F}$ & Incident & Unstated hospital controls & Age, time \\
\hline 13 & Winn I98I [13] & USA & $1975-1978$ & $\mathrm{CCH}$ & $\mathrm{F}$ & Incident and death certificate & No oral cancer or mental disease & Age, race, type, area \\
\hline 14 & Wynder 1983 [99] & USA & $1977-1980$ & $\mathrm{CCH}$ & $M^{f}$ & Histologically confirmed & No tobacco-related diseases & Age, race, hosp, ins \\
\hline 15 & Stockwell 1986 [65] & USA & 1982 & $\mathrm{CCP}$ & $\mathrm{M}+\mathrm{F}$ & Cancer registry 1982 & Melanoma or endocrine cancer & None \\
\hline 16 & Blot $1988[100]$ & USA & $1984-1985$ & $\mathrm{CCP}$ & $M+F$ & Incident & Population controls & Age, sex, area, race \\
\hline 18 & Franco 1989 [102] & Brazil & $1986-1988$ & $\mathrm{CCH}$ & $\mathrm{M}+\mathrm{F}$ & Incident, not lip or salivary glands & No cancer or mental disorder & Age, sex, area, time \\
\hline 19 & Blomqvist 199| [103] & Sweden & up to 1991 & $\mathrm{CCH}$ & $M+F$ & NS & No cancer & Age, sex \\
\hline 20 & Maden $1992[104]$ & USA & $1985-1989$ & $\mathrm{CCP}$ & M & $\begin{array}{l}\text { Squamous cell, 18-65 years, with residential } \\
\text { telephone }\end{array}$ & Population controls & Age, time \\
\hline 21 & Sterling $1992[67]$ & USA & 1986 & $\mathrm{CCP}$ & $M+F$ & $\begin{array}{l}\text { Registered in National Mortality Followback Study } \\
1986 \text {, age } 25+\text { years }\end{array}$ & Population controls & None \\
\hline 22 & Zahm $1992[72]$ & USA & $1954-1980$ & Cohort & M & $\begin{array}{l}\text { US veterans who returned questionnaire on tobacco } \\
\text { use in } 1954 \text { or } 1957\end{array}$ & Mortality 1954-1980 & NA \\
\hline 23 & Mashberg 1993 [68] & USA & $1972-1983$ & $\mathrm{CCH}$ & M & Incident in 1972-1983, US veterans & $\begin{array}{l}\text { No cancer or dysplasia of pharynx, larynx, lung or } \\
\text { oesophagus }\end{array}$ & None \\
\hline 24 & Perry 1993h & USA & about 1992 & $\mathrm{CCH}$ & $M+F$ & NS & Cardiovascular diseases & NS \\
\hline 25 & Kabat 1994 [59] & USA & $1977-1990$ & $\mathrm{CCH}$ & $M+F$ & Incident & No tobacco-related diseases & $\begin{array}{l}\text { Age, sex, race, } \\
\text { hosp, time }\end{array}$ \\
\hline 26 & Bundgaard 1995 [105] & Denmark & $1986-1990$ & $\mathrm{CCP}$ & $M+F$ & Histologically confirmed & Population controls & Age, sex, area \\
\hline 27 & Lewin 1998 [64] & Sweden & $1988-1990$ & $\mathrm{CCP}$ & M & Incident and registered, not identified at autopsy & Population controls & Age, area \\
\hline 28 & Muscat 1998 [106] & USA & $1977-1990$ & $\mathrm{CCH}$ & $M+F$ & Incident, not mentally impaired & No tobacco-related diseases & Age, sex, race, time \\
\hline 29 & Schildt 1998 [73] & Sweden & $1980-1989$ & $\mathrm{CCP}$ & $M+F$ & $\begin{array}{l}\text { Histologically confirmed, not deceased without a } \\
\text { relative }\end{array}$ & Population controls & Age, sex, area, vit \\
\hline 30 & Schwartz 1998 [69] & USA & $1990-1995$ & $\mathrm{CCP}$ & $\mathrm{M}+\mathrm{F}$ & $\begin{array}{l}\text { Histologically confirmed squamous cell carcinoma, } \\
18-65 \text { years }\end{array}$ & Population controls & Age, sex \\
\hline $3 \mathbf{I}$ & Boffetta 2005 [82] & Norway & $1966-200 \mid$ & Cohort & M & Population sample and relatives of migrants to USA & Incidence 1966-200| & NA \\
\hline $\begin{array}{l}\text { a In stud } \\
\text { b CCH } \\
\text { c For co } \\
\text { d NS = } \\
\text { e NS = r } \\
\text { f Exposu } \\
\text { glnsuffic } \\
\text { h Attrib }\end{array}$ & $\begin{array}{l}\text { es } 3 \text { and } 6 \text { the starting ye } \\
\text { case control with hospit } \\
\text { ort studies } \\
\text { ot stated } \\
\text { ot stated, NA = not appli } \\
\text { re data only available for } \\
\text { ient information for femal } \\
\text { table oral cancer risk due }\end{array}$ & $\begin{array}{l}\text { ar of collection } \\
\text { al controls, CC } \\
\text { cable, rel. = rel } \\
\text { nales }\end{array}$ & $\begin{array}{l}\text { of cases was not gi } \\
=\text { case control wit } \\
\text { gion, ins. = insuranc }\end{array}$ & en population & $\begin{array}{l}\text { ontrols } \\
=\text { hospit }\end{array}$ & time $=$ period of admission, occ. $=$ occupation, ty & incident or decedent, vit. = vital & \\
\hline
\end{tabular}


Table 2: Cancer sites considered in the 32 included studies

\begin{tabular}{|c|c|c|c|c|c|c|c|c|c|c|c|c|c|c|c|c|c|c|c|c|c|c|c|c|c|c|c|c|c|c|c|c|}
\hline \multirow[t]{2}{*}{ Cancer site } & \multicolumn{32}{|c|}{ Study numbers } \\
\hline & 1 & 2 & 3 & 4 & 5 & 6 & 7 & 8 & 9 & 10 & 11 & 12 & 13 & 14 & 15 & 16 & 17 & 18 & 19 & 20 & 21 & 22 & 23 & 24 & 25 & 26 & 27 & 28 & 29 & 30 & 31 & 32 \\
\hline Buccal mucosa & & $x$ & $x$ & $x$ & $x$ & & & & $x$ & & & $x$ & & & & & & & & & & & & & $x$ & $x$ & & & & & & \\
\hline Floor of mouth & & $x$ & $x$ & $x$ & $x$ & & & & $x$ & & & & & & $x$ & & & $x$ & & $x$ & & & & & $x$ & $x$ & & & & $x$ & & \\
\hline Gingiva & & & & & $x$ & & & & & & & & & & & & & & & & & & & & $x$ & & & & & & & \\
\hline Gum/palate & & $\mathrm{a}$ & $x$ & & $x$ & & & & $x$ & $x$ & & $x$ & & & $x$ & & & $x$ & & $x$ & & & & & $x$ & $x$ & & & $x$ & $x$ & & \\
\hline Lip & $x$ & $\mathrm{a}$ & $x$ & & $x$ & & & $x$ & & $x$ & & & & & $x$ & & & & $x$ & $x$ & & & & & & & & & $x$ & & & \\
\hline Oral cavity/mouth & & & $x$ & & & $x$ & $x$ & & & $x$ & $x$ & & $x$ & $x$ & & $x$ & $x$ & $x$ & & & $x$ & $x$ & $x$ & $x$ & $x$ & $x$ & $x$ & & $x$ & $x$ & $x$ & $x$ \\
\hline Pharynx/alveolus & & $x$ & $x$ & $x$ & $\mathrm{~b}$ & $x$ & $x$ & & $x$ & $x$ & & & $x$ & $x$ & $x$ & $x$ & $x$ & & & $x$ & $x$ & $x$ & $x$ & & $x$ & $x$ & $x$ & & & $x$ & $x$ & $x$ \\
\hline Tongue & & $\mathrm{a}$ & $x$ & & $x$ & & & & & $x$ & & & & & $x$ & & $x$ & $x$ & & $x$ & & & & & $x$ & $x$ & & & $x$ & $x$ & & \\
\hline Tonsils & & $\mathrm{a}$ & $x$ & & & & & & & & & & & & & & & & & & & & & & $x$ & & & & & $x$ & & \\
\hline Salivary glands & & & & & $x$ & & & & & $x$ & & & & & $x$ & & & & & & & & & & & & & $x$ & & & & \\
\hline Unspecified & & & & & $\mathrm{b}$ & & & & $x$ & & & & & & $x$ & & $x^{c}$ & & & $x$ & & & & $x$ & & & & & & $x$ & & \\
\hline
\end{tabular}

a Specifically excluded by author

b Due to the joint reporting of pharynx and larynx cases, both sites were excluded from analyse

c Larynx cases could not be excluded due to incomplete reporting

Table 3: Study details and effect estimates.

\begin{tabular}{|c|c|c|c|c|c|c|c|c|}
\hline Study & $\begin{array}{l}\text { First author, year } \\
\text { of publication }\end{array}$ & $\begin{array}{l}\text { Method of exposure } \\
\text { assessment }\end{array}$ & Cancer site & Adjustment factors ${ }^{\mathrm{a}}$ & Exposure (period) & Sex & $\begin{array}{l}\text { Cases } / \\
\text { Controls }\end{array}$ & OR/RR'(95\% Cl) \\
\hline \multirow[t]{3}{*}{1} & Broders $1920[74]$ & NS & Lip & Smoking & Chewing (NS) & $M+F$ & $537 / 500$ & $2.05(1.48-2.83)$ de \\
\hline & & & & None & Snuff (NS) & $M+F$ & $537 / 500$ & $1.76(0.12-26.2)^{\mathrm{ef}}$ \\
\hline & & & & None & Smokeless (NS) & $M+F$ & $537 / 500$ & $2.05(1.48-2.83)^{\text {efg }}$ \\
\hline 2 & Moore 1953 [57] & Interview & Buccal mucosa, gum, floor of mouth & None & Smokeless ( $20+$ years $)$ & M & $1 / 2 / 38$ & $3.00(1.37-6.54)^{f}$ \\
\hline 3 & Wynder 1957 [58] & Interview & $\begin{array}{l}\text { Lip, floor of mouth, gum, buccal mucosa, tongue, palate, } \\
\text { tonsil, pharynx }\end{array}$ & Smokingh & Chewing (ever) & M & $525 / 186$ & $2.00(1.16-3.47)^{\text {ef }}$ \\
\hline \multirow[t]{2}{*}{4} & Peacock 1960 [93] & Interview & Buccal mucosa, alveolar ridge, floor of mouth & Age, ins. & Smokeless $(20+$ years $)$ & M & $25 / 191$ & $3.06(1.08-8.63) \mathrm{di}$ \\
\hline & & & & & & $\mathrm{F}$ & $20 / 172$ & $2.00(0.66-6.01)^{\mathrm{di}}$ \\
\hline \multirow[t]{2}{*}{5} & Vogler $1962[62]$ & Interview or questionnaire & $\begin{array}{l}\text { Lip, buccal mucosa, tongue, palate, gingiva, floor of mouth, } \\
\text { minor salivary glandsk }\end{array}$ & None & Chewing (ever) & M & $14 / 402$ & $7.38(4.31-12.62)^{\mathrm{dij}}$ \\
\hline & & & & & Snuff (ever) & $\mathrm{F}$ & $75 / 826$ & $38.28(21.49-68.15)^{\mathrm{dei}}$ \\
\hline 6 & Vincent 1963 [94] & Interview & Oral cavity, pharynx & None & Snuff (NS) & M & $66 / 100$ & $4.22(1.41-12.63)^{\mathrm{fi}}$ \\
\hline \multirow[t]{2}{*}{7} & Martinez 1969 [95] & Interview & Mouth and pharynx & Smokingl & Chewing (last 20 years) & M & $18 / 81$ & $2.29(0.62-8.48)^{f i m}$ \\
\hline & & & & & & $\mathrm{F}$ & $16 / 79$ & $0.34(0.04-2.79)^{\mathrm{fim}}$ \\
\hline 8 & Keller 1970 [75] & Hospital records & Lip & Smoking & Smokeless (NS) & M & $258 / 207$ & $3.63(1.02-12.95)^{d}$ \\
\hline 9 & Browne 1977 [96] & Interview, proxy interview & $\begin{array}{l}\text { Buccal mucosa, upper alveolus and hard palate, lower } \\
\text { alveolus, floor of mouth, pillar of fauces, soft palate, } \\
\text { unspecified or multiple }\end{array}$ & None & Chewing (NS) & $M+F$ & $75 / 150$ & $0.67(0.27-1.66)^{f}$ \\
\hline \multirow[t]{2}{*}{10} & Williams 1977 [97] & Interview & Lip, tongue, salivary glands, gum, mouth, pharynx & None & Smokeless (ever) & M & 190/1788 & $0.91(0.53-1.56)^{\mathrm{fgi}}$ \\
\hline & & & & & & $\mathrm{F}$ & $79 / 3188$ & $1.54(0.37-6.42)^{\mathrm{fgi}}$ \\
\hline \multirow[t]{3}{*}{11} & Wynder 1977 [98] & Interview & Oral cavity & None & Chewing (ever) & M & $591 / 2560$ & $1.15(0.85-1.55)^{f}$ \\
\hline & & & & & Snuff (ever) & M & $591 / 2560$ & $0.62(0.32-1.22)^{f}$ \\
\hline & & & & & Smokeless (ever) & M & $591 / 2560$ & $1.02(0.78-1.34)^{\mathrm{fgn}}$ \\
\hline 12 & Westbrook 1980 [63] & Hospital records & Buccal mucosa, gum & None & Snuff (ever) & $\mathrm{F}$ & $55 / 55$ & $540.0(60.97-4782.82)^{f}$ \\
\hline 13 & Winn 198I [13] & Interview, proxy interview & Mouth and pharynx & Smoking, race & Snuff (ever) & $\mathrm{F}$ & $232 / 410$ & $2.67(1.83-3.90)^{d}$ \\
\hline \multirow[t]{2}{*}{14} & Wynder 1983 [99] & Interview & Oral and pharyngeal & None & Chewing (ever) & M & $4|4 / 4| 4$ & $1.00(0.62-1.61)^{\mathrm{ef}}$ \\
\hline & & & & & Snuff (ever) & M & $4|4 / 4| 4$ & $0.42(0.11-1.65)^{f}$ \\
\hline
\end{tabular}


Table 3: Study details and effect estimates. (Continued)

\begin{tabular}{|c|c|c|c|c|c|c|c|c|}
\hline & & & & & Smokeless (ever) & M & $4|4 / 4| 4$ & $0.90(0.57-1.41)^{\text {efgn }}$ \\
\hline 15 & Stockwell 1986 [65] & Medical records & $\begin{array}{l}\text { Lip, tongue, salivary glands, gum, floor of mouth, other } \\
\text { parts of mouth, pharynx }\end{array}$ & None & Smokeless (ever) & $M+F$ & |462/8285 & $2.02(1.01-4.02)^{f i}$ \\
\hline \multirow[t]{2}{*}{16} & Blot $1988[100]$ & Interview, proxy interview & Oral and pharyngeal & None & Smokeless (ever) & M & $762 / 837$ & $0.85(0.57-1.26)^{e f}$ \\
\hline & & & & & & $\mathrm{F}$ & $352 / 431$ & $3.44(1.09-10.91)^{\mathrm{ef}}$ \\
\hline \multirow[t]{3}{*}{17} & Spitz I988 [10I] & Questionnaire & Larynx, tongue, orohypopharynx, oral cavity ${ }^{\circ}$ & None & Chewing (ever) & $M+F$ & $185 / 185$ & $1.00(0.54-1.85)^{f}$ \\
\hline & & & & NS & Snuff (ever) & $M+F$ & $185 / 185$ & $3.40(1.00-10.90)^{p}$ \\
\hline & & & & None & Smokeless (ever) & $M+F$ & $185 / 185$ & $1.05(0.57-1.91)^{f g}$ \\
\hline 18 & Franco 1989 [102] & Interview & Oral cavity, tongue, gum, floor of mouth & None & Smokeless (ever) & $M+F$ & $232 / 464$ & $1.40(0.59-3.33)^{f}$ \\
\hline 19 & Blomqvist 199| [103] & Questionnaire & Lower lip & Smokingl & Snuff (ever) & $M+F$ & $14 / 10$ & $0.67(0.08-5.75)^{f}$ \\
\hline 20 & Maden 1992 [104] & Interview & $\begin{array}{l}\text { Lip, tongue, gum, floor of mouth, oropharynx, other parts } \\
\text { of mouth }\end{array}$ & Age & Smokeless (ever) & M & $|3| / \mid 36$ & $4.50(1.50-14.30)^{\mathrm{p}}$ \\
\hline \multirow[t]{2}{*}{21} & Sterling 1992 [67] & $\begin{array}{l}\text { Interview (controls), proxy } \\
\text { interview (cases) }\end{array}$ & Oral and pharyngeal & $\begin{array}{l}\text { Smoking, sex, race, age, alc, } \\
\text { occ. }\end{array}$ & Smokeless (100+ times) & $M+F$ & 6976/NS & $1.04(0.4 \mathrm{I}-2.68)^{q}$ \\
\hline & & & & Sex, race, age & Snuff (ever) & $M+F$ & 6976/NS & $2.42(1.28-4.59)^{\mathrm{P}}$ \\
\hline 22 & Zahm 1992 [72] & Questionnaire & Buccal cavity, pharynx & Age, time & Smokeless (ever) & $M$ & |29/248046 & $4.11(2.90-5.84)^{r}$ \\
\hline \multirow[t]{3}{*}{23} & Mashberg 1993 [68] & Interview & Oral cavity, oropharynx & Smoking, age, race, alc. & Snuff (ever) & M & $359 / 2280$ & $0.80(0.40-1.90)^{p}$ \\
\hline & & & & & Chewing (ever) & M & $359 / 2280$ & $1.00(0.70-1.40)^{p}$ \\
\hline & & & & & Smokeless (ever) & M & $359 / 2280$ & $0.96(0.70-1.33)^{n q}$ \\
\hline 24 & Perry 1993s & NS & Oral & $\begin{array}{l}\text { Smoking, age, sex, race, alc, } \\
\text { occ. }\end{array}$ & Smokeless (100+ times) & $M+F$ & $133 / 678$ & $1.43(0.64-3.21)^{q}$ \\
\hline \multirow[t]{2}{*}{25} & Kabat 1994 [59] & Interview & $\begin{array}{l}\text { Tongue, floor of mouth, gums, gingiva, buccal mucosa, } \\
\text { palate, retromolar area, tonsil and other pharynx }\end{array}$ & Smokingl & Snuff (ever) & $M+F$ & $195 / 918$ & $4.79(1.19-19.30)^{f}$ \\
\hline & & & & Smoking & Chewing (ever) & M & 1097/2075 & $1.11(0.8 \mathrm{I}-1.53)^{\mathrm{de}}$ \\
\hline 26 & Bundgaard 1995 [105] & Questionnaire & $\begin{array}{l}\text { Retromolar area, buccal mucosa, floor of mouth, hard } \\
\text { palate, upper alveolus, lower alveolus, tongue }\end{array}$ & None & Chewing (ever) & $M+F$ & $161 / 400$ & $1.44(0.59-3.51)^{d}$ \\
\hline 27 & Lewin 1998 [64] & Interview & Oral and pharyngeal & Smoking, age, area, alc. & Snuff (ever) & M & $266 / 641$ & $0.98(0.63-1.50)^{r}$ \\
\hline \multirow[t]{2}{*}{28} & Muscat 1998 [106] & Interview & Major salivary gland & None & Chewing (ever) & $M+F$ & $128 / 114$ & $0.89(0.18-4.49)^{\mathrm{d}}$ \\
\hline & & & & & Smokeless (ever) & $M+F$ & $128 / 114$ & $1.19(0.26-5.45)^{\mathrm{dgn}}$ \\
\hline \multirow[t]{3}{*}{29} & Schildt 1998 [73] & $\begin{array}{l}\text { Questionnaire from next-of-kin } \\
\text { for deceased cases/controls }\end{array}$ & Lip, tongue, gum, mouth & Smoking, alc. & Snuff (ever) & $M+F$ & $354 / 354$ & $0.80(0.50-1.30)^{\mathrm{P}}$ \\
\hline & & & & None & Chewing (ever) & $M+F$ & $354 / 354$ & $0.60(0.20-2.00)^{p}$ \\
\hline & & & & & Smokeless (ever) & $M+F$ & $354 / 354$ & $0.87(0.61-1.25)^{f g n}$ \\
\hline 30 & Schwartz 1998 [69] & Interview & $\begin{array}{l}\text { Tongue, gum, floor of mouth, tonsils, oropharynx, other } \\
\text { parts of mouth }\end{array}$ & Smoking, age, alc, sex & Smokeless (ever) & $M$ & $165 / 302$ & $1.00(0.40-2.30)^{\mathrm{P}}$ \\
\hline 31 & Boffetta 2005 [82] & Questionnaire & Oral and pharyngeal & Smoking, age & Snuff (ever) & $M$ & $34 / 10136$ & $\mathrm{I} .10(0.50-2.4 \mathrm{I})^{\mathrm{P}}$ \\
\hline \multirow[t]{2}{*}{32} & Henley 2005 [66] & Questionnaire & Oral and pharyngeal & $\begin{array}{l}\text { Smoking', age, race, educ., } \\
\text { alc, exer, asp, bmi, diet, occt. }\end{array}$ & Smokeless (current) & M (CPS- & 13/77407 & $2.02(0.53-7.74)^{P}$ \\
\hline & & & & & Smokeless (ever) & $\begin{array}{l}\text { M (CPS- } \\
\text { II) }\end{array}$ & $46 / 114809$ & $0.90(0.12-6.71)^{p}$ \\
\hline
\end{tabular}

a alc = alcohol consumption, asp = aspirin, bmi = body mass index, educ = education, exer = exercise, ins $=$ insurance status, occ = occupatio

W $c O R=$ odds ratio (case-control studies), $R R=$ relative risk (cohort studies)

$\sim$ e Numbers of exposed and unexposed cases and controls estimated from proportions exposed given numerically

- Estimated from $2 \times 2$ table

I 8 Numbers of exposed cases and controls combined over levels of exposure

h Analysis based on smokers only (only one SLT user was a non-smoker)

iNumbers of exposed and unexposed cases and controls estimated from proportions exposed given graphically

Ane

wing only data for mouth cancer wrongly given under pipe only

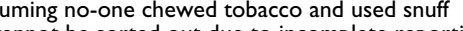

D As reported by the authors
0 a Estimated from non-independent relative risks by level of exposure using method of Fry and Lee

O r Estimated from non-independent relative risks for $c$ ancer types using method of Fry and Lee

torbutable oral cancer risk due to smokeless tobacco use based on a case-control study at Sinai Hospital in Detroit; unpublished 
studies contrasted never and ever use of smokeless tobacco and did not specify any minimal duration of use, but three studies $(2,4,7)$ considered only exposures of 20 years or more. Separate estimates by gender were only available in five studies $(4,7,10,16,25)$. Estimates were only available for chewing tobacco in four studies $(3,7,9$, $26)$, for snuff in six studies $(6,12,13,19,27,31)$ and for unspecified smokeless tobacco use in 12 studies $(2,4,8$, $10,15,16,18,20,22,24,30,32)$. Estimates were available for more than one type of product in the remaining 10 studies $(1,5,11,14,17,21,23,25,28,29)$, all but two (5, 25 ) including an estimate for overall smokeless tobacco use. Most of the estimates were for smokers and nonsmokers combined. Exceptionally, that for chewing tobacco, in study 3, was for smokers, those for chewing tobacco in study 7 were for nonsmokers, those for snuff in studies 19 and 25 were for nonsmokers, and those for smokeless tobacco in study 32 were for nonsmokers. Two effect estimates based on different data sets (the cancer prevention studies CPS-I and CPS-II) were provided by study 32 .

Overall, Table 3 contains 53 effect estimates, of which 11 were provided by the authors and 42 were calculated from data presented. Superscript notes attached to the estimates give some detail on how the calculations were carried out. Non-independent estimates were combined over level of exposure in two studies $(21,24)$, over type of smokeless product in one study (23) and over cancer types in two studies $(22,27)$. In five studies $(11,14,23,28,29) \mathrm{com}-$ bined estimates for smokeless tobacco use were calculated approximately assuming that noone chewed tobacco and used snuff.

As described in Table 3, exposure data were collected directly from patients/controls by interview in 15 studies $(2,3,4,6,7,10,11,14,18,20,23,25,27,28,30)$, by questionnaire in six $(17,19,22,26,31,32)$, and by both in one (5). In five studies $(9,13,16,21,29)$, both direct and proxy interviews were conducted. In four of these, the proportion of proxy interviews was much higher in cases than in controls, and only in study 29 , where controls were matched with cases on vital status, was the proportion the same. Three studies $(8,12,15)$ used medical records for exposure assessment. For study 12 this may have led to the probability of reporting smokeless tobacco use being much higher in cases than in controls $[10,11]$. Two studies $(1,24)$ did not clearly describe the source of exposure assessment.

Overall 16,540 cases of oral cancer were used in the present analysis. Of these, 222 were in three cohort studies $(22,31,32), 5,580$ were in 19 case-control studies with hospital controls $(1-6,8,10-14,17-19,23-25,28)$, 10,704 were in nine case-control studies with population controls $(9,15,16,20,21,26,27,29,30)$, and 34 were in the one case-control study with both types of control (study 7). The first, second and third quartiles of the number of cases considered were 94, 200, and 387. The smallest study had 14 cases (study 19) and the largest 6,976 (study 21, based on a sample of US death certificates of 1986). Excluding study 21, where numbers of controls were not available, a total of 29,009 controls were considered in the 28 case-control studies, of which 17,313 were hospital, 11,536 population and 160 mixed.

Diagnoses of oral cancer were reported as histologically confirmed in 19 studies $(3,4,7,8,11,12,14,16,17,18$, $20,23,25,26,27,28,29,30,31)$ and as confirmed for some of the cases by four studies $(9,10,15,24)$. Histological confirmation was not reported by six studies $(1,2,5$, $6,13,19$ ), and death certificates (presumably without $100 \%$ histological verification) were used in three studies $(21,22,32)$.

Figure 1 presents the 38 study-specific risk estimates and their 95\% CI for all types of smokeless tobacco. Studies conducted before about 1965 uniformly show effect estimates above one, with studies published in the last 10 years or so showing no statistically significant increases. Figures 2 to 4 similarly present, respectively, the estimates for chewing tobacco, snuff and unspecified smokeless tobacco use. Here the estimates are separated according to whether they were unadjusted or adjusted for smoking. The precision of estimates for chewing tobacco is in general higher than the precision for snuff or unspecified smokeless tobacco use. The relatively low precision of estimates for unspecified smokeless tobacco may reflect the variety of exposures investigated. For snuff the smoking adjusted relative risks seem lower than the unadjusted relative risks, but the difference is less marked for chewing tobacco and unspecified smokeless tobacco use. The figures also include results of random-effects meta-analyses, which are discussed in the next section.

\section{Meta-analysis}

Table 4 summarizes the results of the meta-analyses. Separate results are shown based on 14 estimates specifically for chewing tobacco, 15 specifically for snuff, 24 for smokeless tobacco, and 38 for "all" types of smokeless tobacco. Random-effects estimates appear in Table 4 only where heterogeneity was detected.

Based on the 38 estimates for all types of smokeless tobacco shown in Figure 1, the fixed-effect estimate, regardless of adjustment for potential confounding variables, is 1.54. This is similar to the fixed-effect estimate of 1.58 based on studies without any adjustment. In both cases, heterogeneity is observed, substantial enough to 


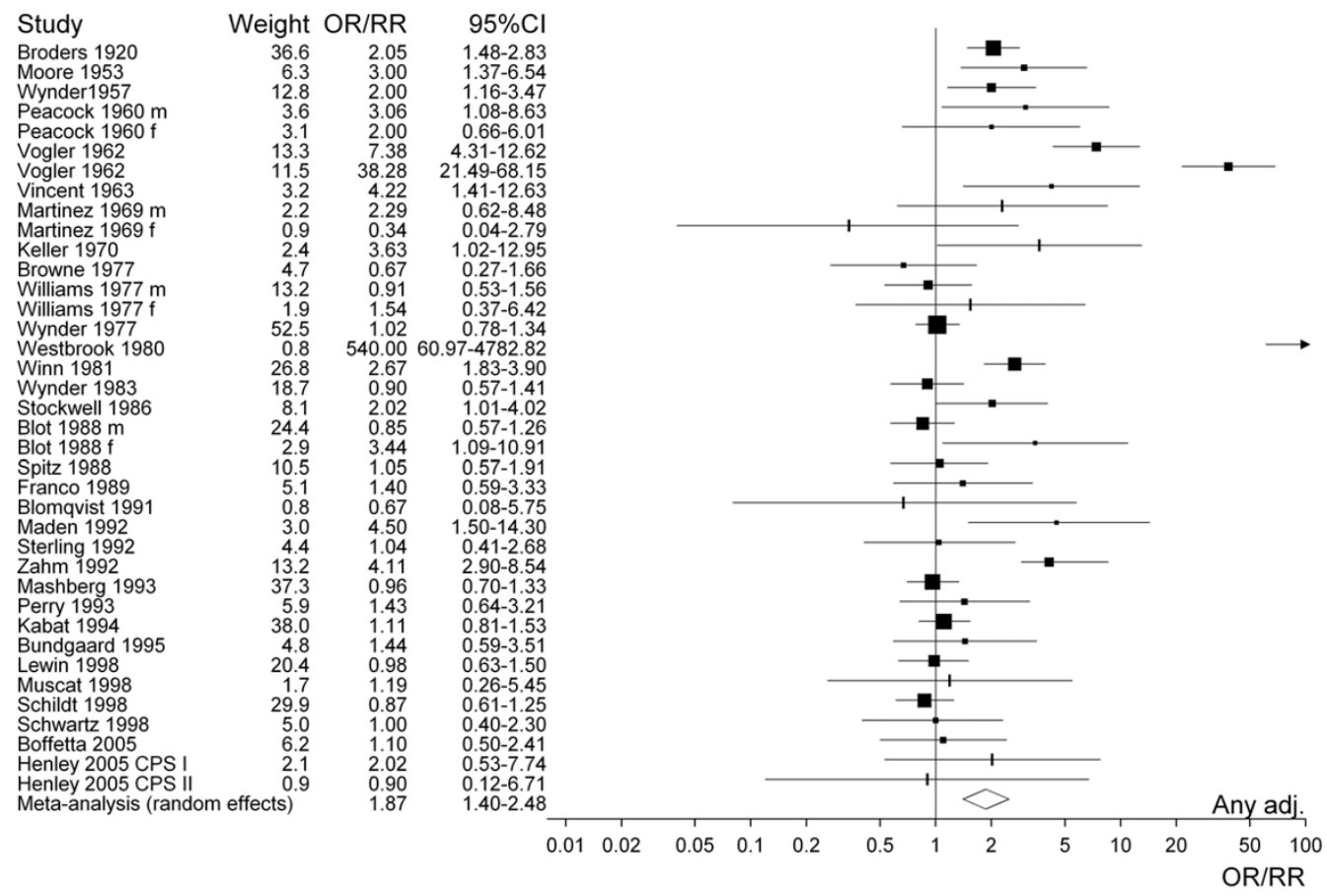

Figure I

Forest plot of study-specific effect estimates and $95 \% \mathrm{Cls}$ for all types of smokeless tobacco use.

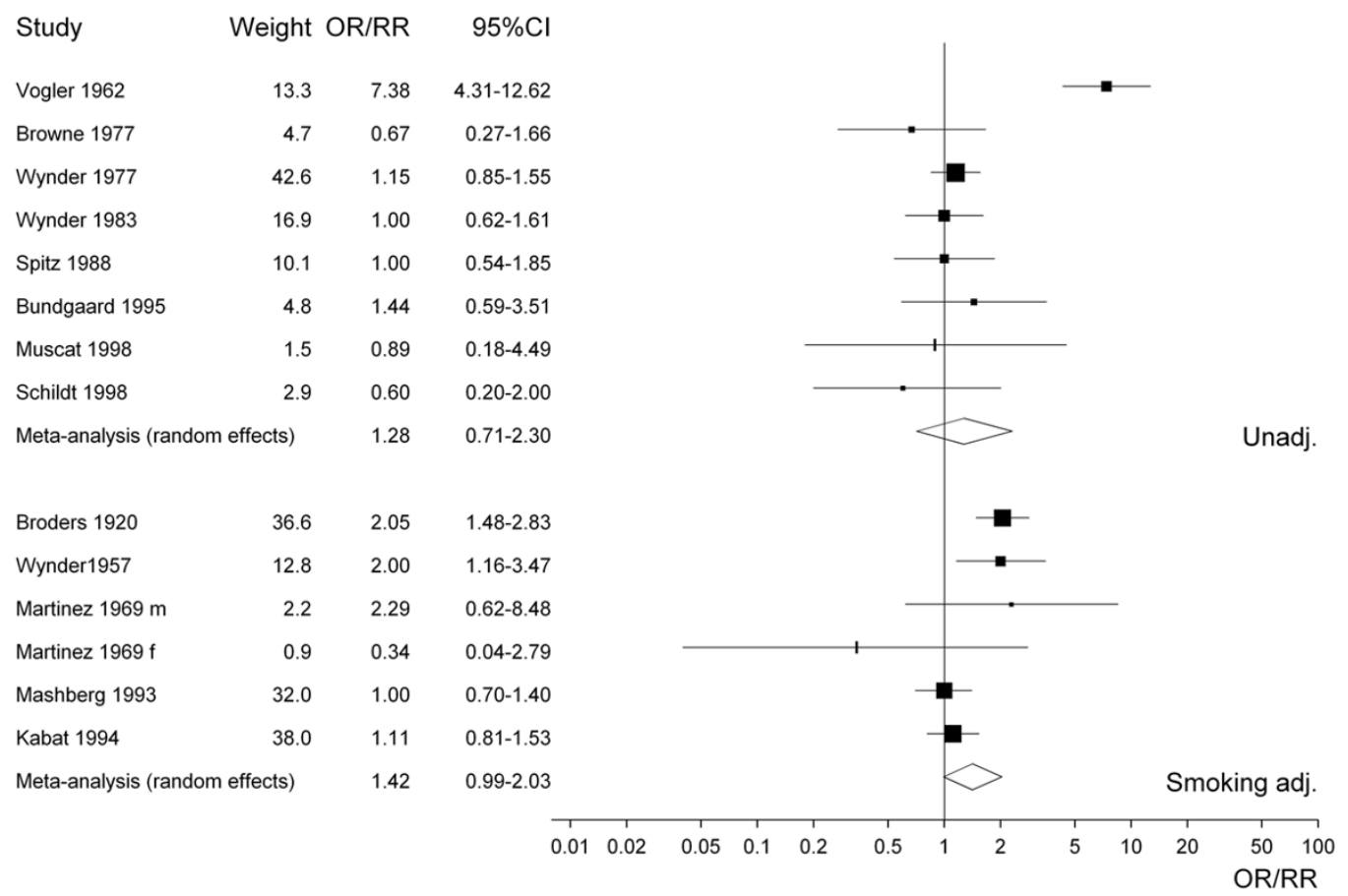

Figure 2

Forest plot of study-specific effect estimates and $95 \% \mathrm{Cls}$ for chewing tobacco. 


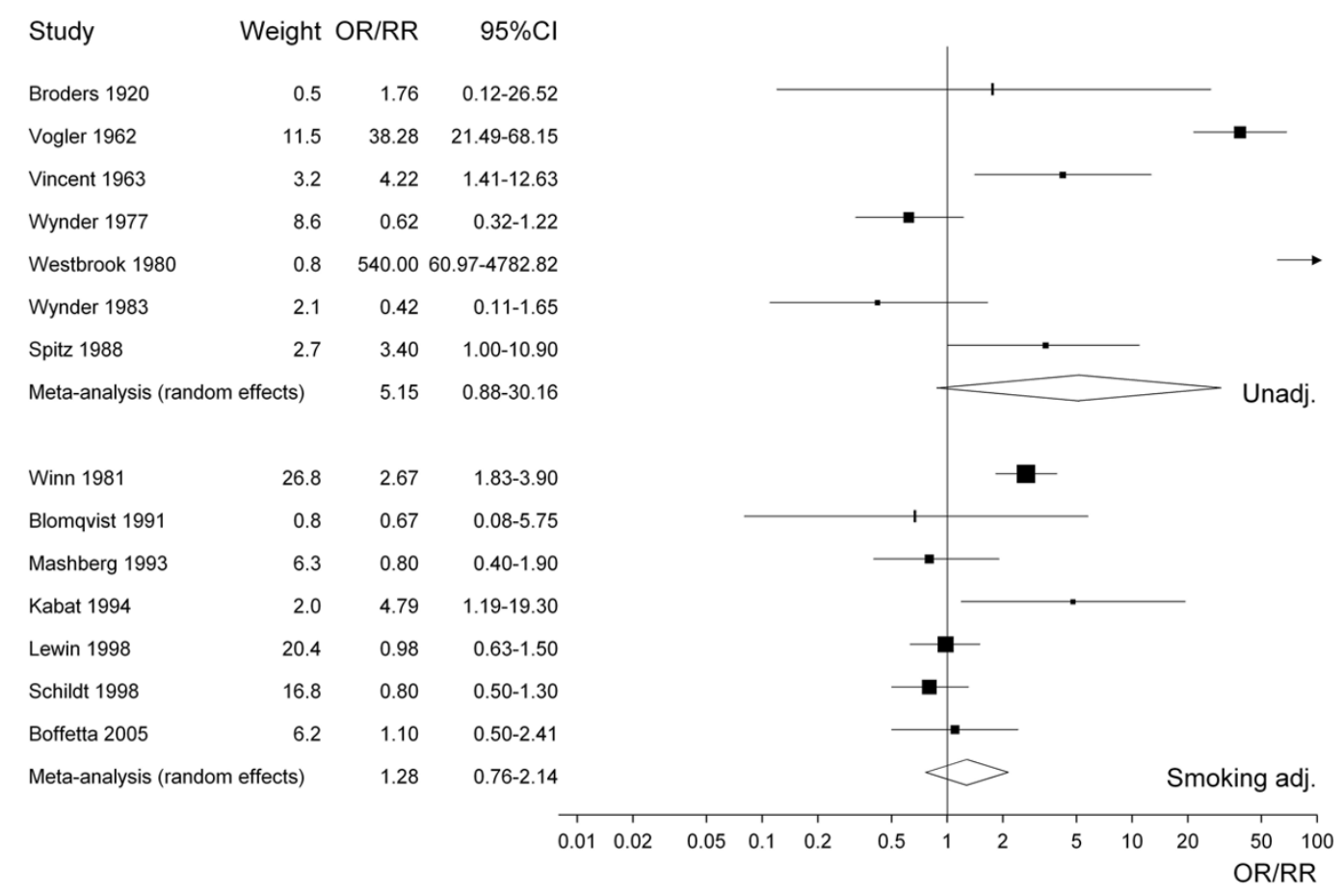

Figure 3

Forest plot of study-specific effect estimates and $95 \%$ Cls for snuff.

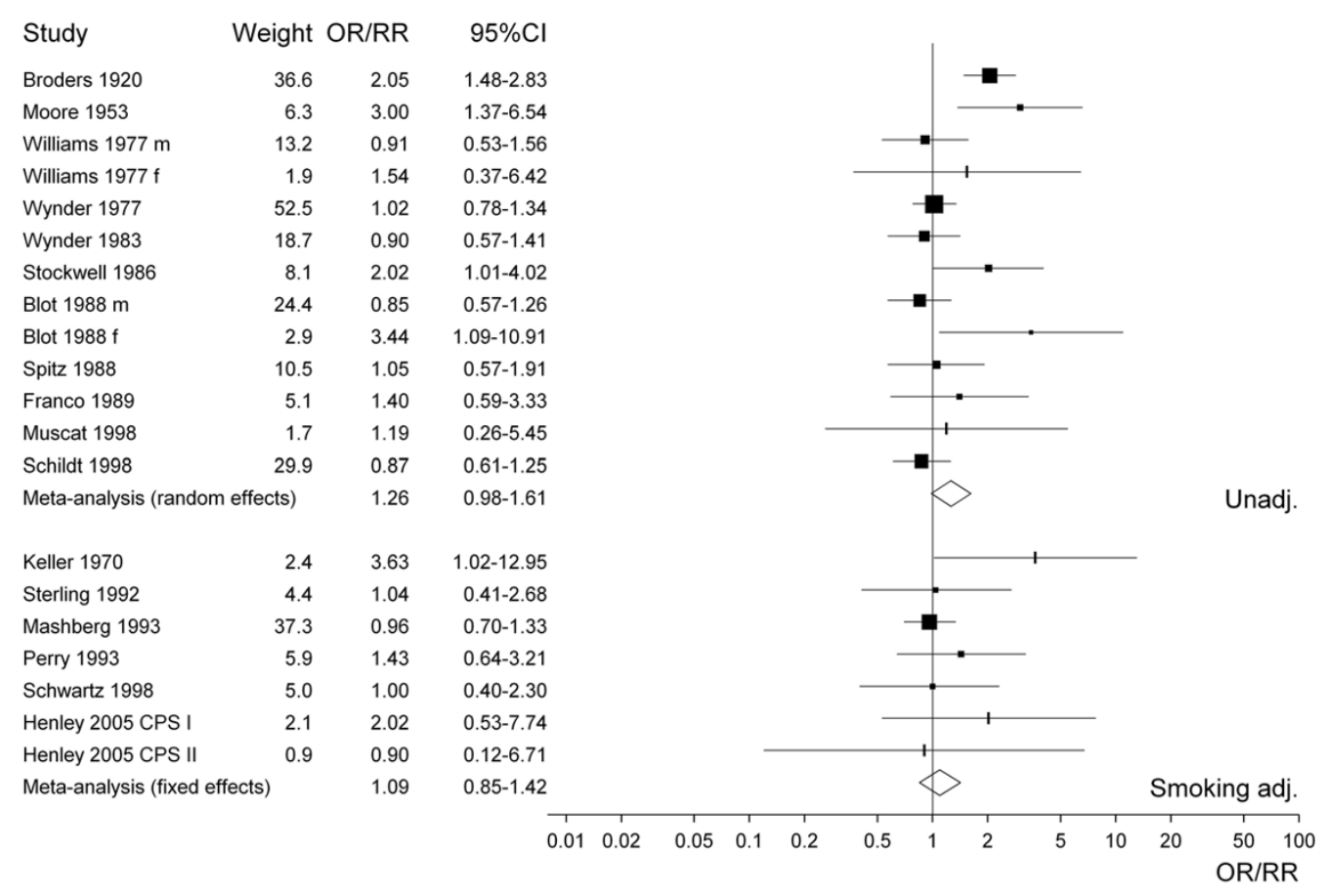

Figure 4

Forest plot of study-specific effect estimates and $95 \%$ Cls for overall smokeless tobacco use. 
Table 4: Meta-analyses of the risk of oral cancer in smokeless tobacco users compared to non-users (based on the estimates given in Table 3).

\begin{tabular}{|c|c|c|c|c|c|c|c|}
\hline \multirow[b]{2}{*}{$\begin{array}{l}\text { Type of } \\
\text { smokeless } \\
\text { tobacco }\end{array}$} & \multirow[b]{2}{*}{$\begin{array}{c}\text { No. of } \\
\text { estimates } \\
\text { combined }\end{array}$} & \multirow[b]{2}{*}{$\begin{array}{l}\text { Adjustment } \\
\text { factors }^{\mathrm{a}}\end{array}$} & \multirow[b]{2}{*}{$\begin{array}{c}\text { Fixed-effect } \\
\text { OR/RR }(95 \% \mathrm{Cl})\end{array}$} & \multirow[b]{2}{*}{$\begin{array}{l}\text { Random-effects } \\
\text { OR/RR }(95 \% \mathrm{Cl})\end{array}$} & \multicolumn{2}{|c|}{ Heterogeneity } & \multirow[b]{2}{*}{$\mathrm{P}\left(\chi^{2}\right)$} \\
\hline & & & & & $\chi^{2}$ & $1^{2}$ & \\
\hline \multirow[t]{5}{*}{ Allb } & 38 & any & $1.54(1.40-1.69)$ & $1.87(1.40-2.48)$ & 283.3 & 86.9 & $<0.0001$ \\
\hline & 19 & none & $1.58(1.39-1.78)$ & $2.18(1.35-3.53)$ & 232.1 & 92.2 & $<0.0001$ \\
\hline & 15 & $\mathrm{sm}$ & $1.31(1.13-1.53)$ & $1.35(1.04-1.76)$ & 28.7 & 51.3 & 0.0114 \\
\hline & 7 & sm, al & $1.02(0.82-1.28)$ & & 1.9 & 0.0 & 0.9321 \\
\hline & 7 & sm, al, age & $1.02(0.82-1.28)$ & & 1.9 & 0.0 & 0.9321 \\
\hline \multirow[t]{4}{*}{ Chewing } & 14 & any & $1.38(1.21-1.58)$ & $1.36(0.98-1.89)$ & 61.2 & 78.8 & $<0.0001$ \\
\hline & 8 & none & $1.37(1.13-1.68)$ & I.28 (0.7I-2.30) & 46.4 & 84.9 & $<0.0001$ \\
\hline & 6 & sm & $1.39(1.16-1.66)$ & $1.42(0.99-2.03)$ & 14.9 & 66.3 & 0.0110 \\
\hline & 1 & sm, al, age & $1.00(0.7|-| .4 \mid)$ & & -- & -- & -- \\
\hline \multirow[t]{5}{*}{ Snuff } & 15 & any & $2.00(1.67-2.39)$ & $2.39(1.17-4.89)$ & 182.4 & 92.3 & $<0.0001$ \\
\hline & 7 & none & $5.36(3.73-7.69)$ & $5.15(0.88-30.2)$ & 116.7 & 94.9 & $<0.0001$ \\
\hline & 7 & sm & $1.35(1.09-1.69)$ & $1.28(0.76-2.14)$ & 24.8 & 75.8 & 0.0004 \\
\hline & 3 & sm, al & $0.88(0.65-1.18)$ & & 0.4 & 0.0 & 0.7998 \\
\hline & 2 & sm, al, age & $0.93(0.64-1.36)$ & & 0.2 & 0.0 & 0.6555 \\
\hline \multirow[t]{5}{*}{ Smokeless ${ }^{c}$} & 24 & any & $1.27(1.13-1.42)$ & $1.46(1.17-1.83)$ & 65.6 & 65.0 & $<0.0001$ \\
\hline & 13 & none & $1.18(1.03-1.35)$ & $1.26(0.98-1.61)$ & 31.5 & 61.9 & 0.0017 \\
\hline & 7 & $\mathrm{sm}$ & $1.09(0.85-1.42)$ & & 5.4 & 0.0 & 0.4967 \\
\hline & 6 & sm, al, age & $1.04(0.80-1.35)$ & & 1.8 & 0.0 & $0.875 I$ \\
\hline & 4 & sm, al, age, ss & $1.32(0.77-2.25)$ & & 0.8 & 0.0 & 0.8467 \\
\hline
\end{tabular}

\footnotetext{
a Smoking (sm), alcohol (al), age, social status (ss)

b For each study/sex, the OR/RR for smokeless tobacco from Table 3 was included if available, otherwise that for chewing tobacco or snuff was used. For study 25 where estimates for snuff and chewing tobacco, but not smokeless tobacco, were available, that for chewing tobacco was included as it was for smokers and nonsmokers combined

c This includes all the OR/RR estimates from Table 3 where the exposure was smokeless, both from studies where only estimates for unspecified exposure were available and from studies where it had been estimated from the separate data for chewing tobacco and snuff
}

cast some doubts on the corresponding random-effects estimates.

When only those estimates adjusted for smoking are considered, the heterogeneity is markedly reduced, and the fixed-effect estimate also reduces, to 1.31. Since significant heterogeneity remains, the random-effects estimate of 1.35 is the preferred overall estimate. When the analysis is further restricted to estimates adjusted for both smoking and alcohol consumption, no heterogeneity is seen. Moreover, the point estimate is close to unity $(1.02 ; 95 \%$ CI 0.82-1.28). The lack of detectable risk when these factors are accounted for seems consistent with an important confounding effect of smoking and alcohol, both well known major risk factors for oral cancer. For example, Döbróssy [61] reports that smoking and alcohol consumption each "may account for a two- to three-fold increase in risk" and "when tobacco smoking and alcohol consumption are combined, they may increase the risk by more than 15-fold."
The same pattern of estimates decreasing after adjustment for smoking and alcohol can be seen from the separate results for chewing tobacco, snuff and unspecific smokeless tobacco, although for snuff and particularly chewing tobacco numbers of estimates adjusted for both factors are very low. None of the analyses show any significant increase in risk following adjustment for both factors.

The elevated random-effects estimate 5.15 for snuff based on unadjusted data (see also Figure 3 ) is mainly due to two studies with evident weaknesses $[62,63]$. The study by Vogler et al. [62] did not match controls to cases and the effect estimate of 38.28 (21.49-68.15) was computed based on rather incompletely reported information. With regard to the study by Westbrook et al. [63], both IARC [10] and the US Surgeon General [11] pointed out that the risk estimate of $540.0(60.97-4782.82)$ is very unreliable, exposure assessment being based on hospital records, where documentation of smokeless tobacco use is much more likely in cases than in controls. Omitting these two studies, the unadjusted random-effects estimate 
for snuff falls to $1.40(0.51-3.86)$, with the $\mathrm{I}^{2}$ value reduced from 94.9 to 71.6 .

\section{Sensitivity analyses}

Of the 38 estimates included in the all smokeless tobacco analyses, six (from studies 3, 7, 19 and 32) were for smokers or for nonsmokers. Eliminating these estimates so that all the data were for smokers and nonsmokers combined reduced the fixed-effect estimate only slightly, from 1.54 $(1.40-1.69)$ to $1.53(1.39-1.68)$ but increased the random-effects estimate from $1.87(1.40-2.48)$ to 1.94 (1.43-2.65).

Of the 38 estimates, five (from studies 11, 14, 23, 28 and 29) were derived approximately assuming that there were no joint users of chewing tobacco and snuff. Replacing these by estimates for chewing tobacco in US studies and for snuff in Swedish studies increased the fixed-effect estimate to $1.62(1.47-1.78)$ but left the random-effects estimate the same at $1.87(1.40-2.50)$.

\section{Heterogeneity}

Of the 38 estimates used in the all smokeless tobacco analyses, only five were provided directly in the publications, the remaining 33 being derived from the data available. Although fixed-effect estimates were lower for the published data $(1.21 ; 0.78-1.89)$ than for the derived data $(1.55 ; 1.41-1.71)$, the difference was not statistically significant $\left(\chi^{2}=1.15, \mathrm{p}=0.28\right)$. Although the number of published estimates is too few for reliable interpretation, this suggests that no bias to the null has been introduced by considering derived estimates.

A more detailed heterogeneity analysis was also undertaken (Table 5). Since the number of estimates for specific types of smokeless tobacco (14 for chewing tobacco and 15 for snuff) was rather small, and subdivision for possible sources of heterogeneity would have resulted in various cells containing at most a single study, this analysis was conducted using the estimates included in the all smokeless tobacco analyses. Since there were few estimates that were adjusted for both smoking and alcohol consumption, and few adjusted estimates which did not include smoking as one of the factors adjusted for, the heterogeneity analyses were conducted based firstly on the 19 estimates that were unadjusted for any factor and second on the 15 estimates that were adjusted for smoking, regardless of any other adjustment. This left a reasonable number of individual estimates in each of the two sets to investigate the possible role of type of smokeless tobacco, sex, study design, study location and study period on the estimated effect.

Since the potential sources of heterogeneity must be considered as competing, and because of possible residual confounding, for example due to alcohol consumption, the analyses probably overestimate the true contributions to heterogeneity of the individual factors assessed. True proportions of explained heterogeneity could only be estimated from multifactorial analyses of primary data.

By far the most profound source of heterogeneity was study period. In smoking-adjusted estimates, 81.4 percent of the total heterogeneity was accounted for by betweenperiod heterogeneity. Studies conducted before 1980 showed an excess risk, while no increase was seen from studies conducted in 1980 or later. In smoking-unadjusted estimates, period also accounted for a large proportion $(46.9 \%)$ of the total heterogeneity.

Although $67.7 \%$ of the total heterogeneity could be accounted for by type of tobacco in the unadjusted analyses, the corresponding proportion for the smokingadjusted risk estimates was only $15.1 \%$. Although the smoking-adjusted effect estimates for chewing tobacco (1.29) and snuff (1.62) were elevated, this may reflect uncontrolled confounding by alcohol as no increase was seen in the analyses in Table 4 based on estimates adjusted for smoking and alcohol.

Studies conducted in the US indicated an increased risk of oral cancer in both unadjusted data (by 76\%) and adjusted data (by 39\%). Though no significant effect was seen in Scandinavia or in other countries, numbers of estimates were relatively few ( 2 in Scandinavia, 1 in UK and 1 in Brazil for the unadjusted data; 3 in Scandinavia, 2 in Puerto Rico for the adjusted data), and heterogeneity by location was only demonstrated for the unadjusted data.

Sex-specific overall risk estimates were higher for women than men. The fact that the sex difference was larger using unadjusted estimates suggests that at least part of it may be due to confounding.

Hospital-based case-control studies provided higher risk estimates than those from other study designs, and their estimates were much more heterogeneous. The reason for this is unclear.

Figure 5 plots all study-specific effect estimates on a logarithmic scale against their precision. There is only a slight inverse association between precision and variability of individual estimates around the overall random-effects estimate of 1.87 (dotted vertical line). The observed asymmetry of the funnel plot suggests that publication bias cannot be excluded.

\section{Never smokers}

While the previous analyses are based on results, where available, for the whole population studied, including 
Table 5: Heterogeneity of the oral cancer smokeless tobacco relative risk, unadjusted and adjusted for cigarette smoking (based on the estimates given in Table 3).

\begin{tabular}{|c|c|c|c|c|c|c|c|c|c|c|}
\hline \multirow[b]{3}{*}{ Factor } & \multicolumn{5}{|c|}{ Unadjusted for any factor } & \multicolumn{5}{|c|}{ Adjusted for smoking } \\
\hline & \multicolumn{6}{|c|}{ Heterogeneity ${ }^{b}$} & \multicolumn{4}{|c|}{ Heterogeneity ${ }^{b}$} \\
\hline & $N$ & $\begin{array}{l}\text { OR/RR } \\
(95 \% \mathrm{Cl})^{\mathrm{a}}\end{array}$ & $\chi^{2}$ & $1^{2}$ & $\mathrm{p}\left(\chi^{2}\right)^{\mathrm{c}}$ & $\mathrm{N}$ & $\begin{array}{l}\text { OR/RR } \\
(95 \% \mathrm{Cl})^{\mathrm{a}}\end{array}$ & $\chi^{2}$ & $1^{2}$ & $\mathrm{p}\left(\chi^{2}\right)^{\mathrm{c}}$ \\
\hline All estimates ${ }^{d}$ & 19 & $\begin{array}{c}1.58 \\
(1.39-1.78)\end{array}$ & 232.1 & 92.2 & $<0.0001$ & 15 & $\begin{array}{c}1.31 \\
(1.13-1.53)\end{array}$ & 28.7 & 51.3 & 0.0114 \\
\hline \multicolumn{11}{|l|}{ Type } \\
\hline Chewing tobacco & 3 & $\begin{array}{c}3.20 \\
(2.12-4.82)\end{array}$ & 23.8 & 91.6 & $<0.0001$ & 4 & $\begin{array}{c}1.29 \\
(0.99-1.69)\end{array}$ & 5.6 & 46.2 & 0.1342 \\
\hline Snuff & 3 & $\begin{array}{c}27.9 \\
(17.0-45.9)\end{array}$ & 19.6 & 89.8 & 0.0001 & 4 & $\begin{array}{c}1.62 \\
(1.24-2.11)\end{array}$ & 13.4 & 77.7 & 0.0038 \\
\hline Smokeless & 13 & $\begin{array}{c}1.18 \\
(1.03-1.35)\end{array}$ & 31.5 & 61.9 & 0.0017 & 7 & $\begin{array}{c}1.09 \\
(0.85-1.42)\end{array}$ & 5.4 & 0.0 & 0.4967 \\
\hline Between levels & & & 157.3 & 67.7 & $<0.0001$ & & & 4.3 & 15.1 & 0.1142 \\
\hline \multicolumn{11}{|l|}{ Sex } \\
\hline Female & 4 & $\begin{array}{c}20.3 \\
(12.6-32.5)\end{array}$ & 35.0 & 91.4 & $<0.0001$ & 2 & $\begin{array}{c}2.51 \\
(1.73-3.64)\end{array}$ & 3.5 & 71.5 & 0.0610 \\
\hline Male & 7 & $\begin{array}{c}1.27 \\
(1.07-1.5 \mathrm{I})\end{array}$ & 60.6 & 90.1 & $<0.0001$ & 10 & $\begin{array}{c}1.15 \\
(0.97-1.37)\end{array}$ & 10.8 & 16.4 & 0.2925 \\
\hline Both & 8 & $\begin{array}{c}1.35 \\
(1.11-1.64)\end{array}$ & 16.5 & 57.5 & 0.0213 & 3 & $\begin{array}{c}1.19 \\
(0.66-2.15)\end{array}$ & 0.6 & 0.0 & 0.7573 \\
\hline Between levels & & & 120.1 & 51.7 & $<0.0001$ & & & 13.9 & 48.4 & 0.0010 \\
\hline \multicolumn{11}{|l|}{ Study design } \\
\hline Case-control, hospital controls & 13 & $\begin{array}{c}1.90 \\
(1.64-2.21)\end{array}$ & 200.4 & 94.0 & $<0.0001$ & 7 & $\begin{array}{c}|.4| \\
(1.18-\mid .68)\end{array}$ & 22.0 & 73.7 & 0.0009 \\
\hline $\begin{array}{r}\text { Case-control, population } \\
\text { controls }\end{array}$ & 6 & $\begin{array}{c}\mathrm{I} .0 \mathrm{I} \\
(0.8 \mathrm{I}-\mathrm{I} .27)\end{array}$ & 11.0 & 54.6 & 0.0514 & 3 & $\begin{array}{c}0.99 \\
(0.69-1.42)\end{array}$ & 0.0 & 0.0 & 0.9935 \\
\hline Case-control, mixed controls & 0 & -- & -- & -- & -- & $2^{f}$ & $\begin{array}{c}1.35 \\
(0.44-4.13)\end{array}$ & -- & -- & 0.1337 \\
\hline Cohort & 0 & -- & -- & -- & -- & 3 & $\begin{array}{c}1.24 \\
(0.65-2.36)\end{array}$ & -- & -- & 0.7062 \\
\hline Between levels & & & 20.7 & 8.9 & $<0.0001$ & & & 3.0 & 10.4 & 0.3928 \\
\hline \multicolumn{11}{|l|}{ Study location } \\
\hline USA & 15 & $\begin{array}{c}1.76 \\
(1.54-2.02)\end{array}$ & 215.6 & 93.5 & $<0.0001$ & 10 & $\begin{array}{c}1.39 \\
(1.17-1.64)\end{array}$ & 23.7 & 62.1 & 0.0047 \\
\hline Scandinavia & 2 & $\begin{array}{c}0.93 \\
(0.67-1.30)\end{array}$ & 1.1 & 5.3 & 0.3041 & 3 & $\begin{array}{c}0.99 \\
(0.68-1.45)\end{array}$ & 0.2 & 0.0 & 0.9054 \\
\hline Other & $2^{g}$ & $\begin{array}{c}0.99 \\
(0.53-1.84)\end{array}$ & 1.3 & 24.6 & 0.2495 & $2^{\mathrm{h}}$ & $\begin{array}{c}1.35 \\
(0.44-4.13)\end{array}$ & 2.2 & 55.5 & 0.1337 \\
\hline Between levels & & & 14.2 & 6.1 & 0.0008 & & & 2.5 & 8.8 & 0.2810 \\
\hline \multicolumn{11}{|l|}{ Study period } \\
\hline-1969 & 5 & $\begin{array}{c}4.49 \\
(3.55-5.66)\end{array}$ & 79.8 & 95.0 & $<0.0001$ & 4 & $\begin{array}{c}2.02 \\
(1.28-3.20)\end{array}$ & 3.6 & 15.8 & 0.3129 \\
\hline $1970-1979$ & 5 & $\begin{array}{c}1.05 \\
(0.84-1.33)\end{array}$ & 33.0 & 87.9 & $<0.0001$ & I & $\begin{array}{c}2.67 \\
(1.83-3.90)\end{array}$ & 0.0 & 0.0 & -- \\
\hline $1980-1989$ & 7 & $\begin{array}{c}1.01 \\
(0.83-1.23)\end{array}$ & 10.4 & 42.4 & 0.1080 & 2 & $\begin{array}{c}0.97 \\
(0.7|-| .3 \mid)\end{array}$ & 0.0 & 0.0 & 0.8743 \\
\hline $1990+$ & 2 & $\begin{array}{c}1.37 \\
(0.64-2.96)\end{array}$ & 0.0 & 0.0 & 0.8321 & 8 & $\begin{array}{c}1.10 \\
(0.88-1.37)\end{array}$ & 1.8 & 0.0 & 0.9719 \\
\hline Between levels & & & 108.9 & 46.9 & $<0.0001$ & & & 23.4 & 81.4 & $<0.0001$ \\
\hline
\end{tabular}

\footnotetext{
a Fixed-effect estimates

b For the "Between levels" rows, the $\mathrm{I}^{2}$ column contains the percentage of variation explained by the factor levels rather than the heterogeneity $\mathrm{I}^{2}$ statistic

c The probability for the heterogeneity $\chi^{2}$ between studies within levels is shown, except that for the "Between levels" rows, the probability is for the between levels $\chi^{2}$

d For each study/sex, the OR/RR for smokeless tobacco from Table 3 was included if available, otherwise that for chewing tobacco or snuff was used. For study 25 where estimates for snuff and chewing tobacco, but not smokeless tobacco, were available, that for chewing tobacco was included as it was for smokers and nonsmokers combined

e This includes all the OR/RR estimates from Table 3 where the exposure was smokeless, both from studies where only estimates for unspecified exposure were available and from studies where it had been estimated from the separate data for chewing tobacco and snuff

f In study 7 (two estimates), both hospital and population controls were used

g Studies 9 (UK) and 18 (Brazil)

h Study 7 (conducted in Puerto Rico, two estimates)

I Since only one study with an effect estimate adjusted for smoking was conducted between 1970 and 1979 (study I3), an additional assessment of heterogeneity was carried out based on two periods (-1979 vs. 1980+). The corresponding overall effect estimates, based on 5 and I0 studies respectively, were $2.39(1.78-3.19)$ and $1.05(0.88-1.26)$, with $p<0.0001$ for between levels heterogeneity
} 


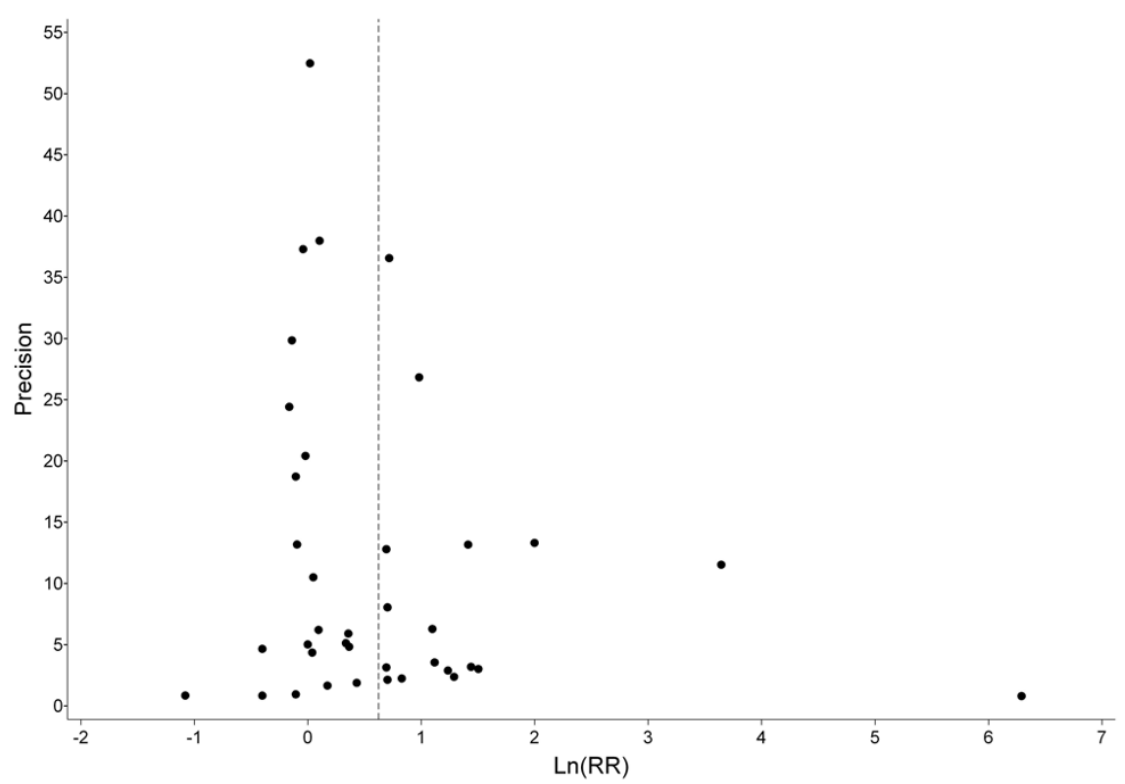

Figure 5

Funnel plot of 38 study-specific effect estimates against precision (I/variance of log effect estimate).

smokers and never smokers, six studies provided oral cancer relative risks specifically among never smokers. The estimates, two for snuff use and four for general smokeless tobacco use, are summarized in Table 6, as are meta-analysis results. Numbers of exposed cases are extremely low, only 44 in total, and six or less for all but one of the estimates. Although the data are somewhat suggestive of an association, neither the fixed-effect estimate of 1.30 (95\%CI 0.82-1.93) nor the random-effects estimate of $1.94(0.88-4.28)$ is statistically significant and the data are heterogeneous $\left(\mathrm{I}^{2}=63.1\right)$. Also shown in Table 6 is an additional age- and region-adjusted estimate of 4.70 (1.60-13.80) for ever snuff use in males. This estimate is for oral, larynx and oesophagus cancer combined, so does not satisfy our original inclusion criteria. Were it included, the random-effects estimate would become significant, at 2.20 (1.04-4.67).

\section{Discussion}

This report is based on data relating oral cancer risk to the consumption of chewing tobacco and snuff as used in Western countries. Our main analyses, based on results for smokers and nonsmokers combined where possible, considers 53 individual effect estimates based on 32 studies published from 1920 to 2005. This represents 11 more studies than considered in the previous most recent quantitative review of the evidence[16]. 16,540 cases of oral cancer were included in studies of different design, size, and quality. Many of the 32 reports have limitations and present less information than is ideal for a meta-analysis.
Shortcomings include small numbers of cases (particularly exposed cases), lack of histological confirmation, lack of division by cancer site, as well as an unclear description of inclusion and exclusion criteria, details of case and control selection, and methods of exposure assessment. Furthermore, exposure details such as type of smokeless tobacco, duration and frequency of use were often not considered. At the analysis level the main weaknesses were failure to adjust results for important potential confounders and to present results separately for major subgroups, particularly by sex, smoking and alcohol. These weaknesses inevitably limit the inferences that can be drawn. Nevertheless some conclusions can be drawn from the present results.

Apart from the diversity of designs, samples, procedures, methods, and types of smokeless tobacco investigated, the individual effect estimates were themselves highly variable, particularly for snuff, where the $\mathrm{I}^{2}$ statistic for the 15 estimates was 94.9 (see also Figure 1). Given the wellknown strong relationships of smoking and alcohol consumption to oral cancer risk [52], and given that 33 of the 53 estimates were unadjusted for either smoking or alcohol, it was perhaps unsurprising that this heterogeneity was highly reduced, and indeed essentially eliminated ( $\mathrm{I}^{2}$ $=0$ for each of the types of smokeless tobacco) by restricting attention to estimates adjusted for these two variables. Not only did such adjustment remove the substantial heterogeneity, but it removed the association, with an overall estimate for all smokeless tobacco use of 1.87 (1.40-2.48) 
Table 6: Effect estimates for never smokers ${ }^{a}$

\begin{tabular}{|c|c|c|c|c|c|c|}
\hline Study & $\begin{array}{l}\text { First author, year of } \\
\text { publication }\end{array}$ & Adjustment factors & Exposure & Sex & Exposed cases & OR/RR $(95 \% \mathrm{Cl})$ \\
\hline \multicolumn{7}{|c|}{ Studies providing result specific for oral cancer } \\
\hline 8 & Keller 1970 [75] & None & Smokeless & M & 4 & $3.04(0.62-14.99)$ \\
\hline 16 & Blot $1988[100]$ & $\begin{array}{l}\text { Age, race, location, } \\
\text { respondent }\end{array}$ & Smokeless & $\mathrm{F}$ & 6 & $6.20(1.90-19.80)$ \\
\hline 19 & Blomqvist I99| [103] & None & Snuff & $M+F$ & 2 & $0.67(0.08-5.75)$ \\
\hline \multirow[t]{2}{*}{25} & Kabat 1994 [59] & None & Smokeless & M & 4 & $1.59(0.5 \mathrm{I}-4.96)$ \\
\hline & & & & $\mathrm{F}$ & 4 & $38.7(2.1-723.6)^{\mathrm{b}}$ \\
\hline 29 & Schildt 1998 [73] & Age, sex, residence & Snuff & $M+F$ & 19 & $0.70(0.40-1.20)$ \\
\hline \multirow[t]{7}{*}{32} & Henley 2005 [66] & $\begin{array}{l}\text { Age, race, education, } \\
\text { alcohol, exercise, aspirin, } \\
\text { body mass index, diet, } \\
\text { occupation }^{c}\end{array}$ & Smokeless & $M(C P S-I)$ & 4 & $2.02(0.53-7.74)$ \\
\hline & & & & $M(C P S-I I)$ & 1 & $0.90(0.12-6.71)$ \\
\hline & & \multicolumn{4}{|c|}{ Fixed-effect meta-analysis estimate for six studies } & $1.30(0.87-1.93)$ \\
\hline & & \multicolumn{4}{|c|}{ Random-effects meta-analysis estimate for six studies } & $1.94(0.88-4.28)$ \\
\hline & & \multirow{3}{*}{\multicolumn{2}{|c|}{ Heterogeneity }} & $\chi^{2}(\mathrm{df})$ & & $18.99(7)$ \\
\hline & & & & $\mathrm{P}$ & & 0.0082 \\
\hline & & & & 12 & & 63.13 \\
\hline
\end{tabular}

Additional study providing result for oral, larynx and oesophagus cancer combined

\begin{tabular}{|c|c|c|c|c|c|}
\hline 27 & Lewin 1998 [64] & Age, region & Snuff & 9 & $4.70(1.60-13.80)$ \\
\hline & & \multicolumn{3}{|c|}{ Fixed-effect meta-analysis estimate for all seven studies } & $1.51(1.04-2.19)$ \\
\hline & & \multicolumn{3}{|c|}{ Random-effect meta-analysis estimate for all seven studies } & $2.20(1.04-4.67)$ \\
\hline & & \multirow[t]{3}{*}{ Heterogeneity } & $\chi^{2}(\mathrm{df})$ & & $23.82(8)$ \\
\hline & & & $\mathrm{p}$ & & 0.0025 \\
\hline & & & $1^{2}$ & & 66.42 \\
\hline
\end{tabular}

aSee the discussion section for the reasons why data from study 15 [65] were not included in Table 6

b There were no exposed controls and the OR was estimated by adding 0.5 to each cell in the $2 \times 2$ table

cOccupation only adjusted for in CPS-II

reducing to $1.02(0.82-1.28)$. The latter estimate is consistent with risk of oral cancer being independent of smokeless tobacco use, though a small increase cannot of course be totally excluded.

The lower effect estimates seen in studies that adjust for alcohol and smoking need not wholly be due to the adjustment. For example, unadjusted estimates may derive from studies which are methodologically weaker, perhaps because smokeless tobacco was not a central issue. As such it is important to look at other information which may cast light on the role of confounding by alcohol or smoking. One way of attempting to eliminate potential confounding effects of smoking is to restrict attention to study of the effects of smokeless tobacco use in never smokers. Unfortunately only six studies provided effect estimates for oral cancer or data from which these could be calculated. Although the data are suggestive of an association, the meta-analysis estimates (see Table 6) are inconclusive and the data are heterogeneous. They are also no doubt open to publication bias, since many researchers would not present null results based on very limited data. These data involve very few exposed cases. Any data available for subjects who have never smoked and never used alcohol would be even sparser. As can be seen from Table 6, one additional study [64] provided results that were not for oral cancer specifically, but included other forms of head and neck cancer. Inclusion of these results do not affect the above conclusions. Another study [65] also seemed at first glance to provide possibly relevant results, with significant increases noted for some oral sites and not others. However this study only asked about the primary type of tobacco used, comparing smokeless tobacco users, who may well also have smoked, with subjects who never used any tobacco product at all. These results are clearly not restricted to never smokers and are open to confounding.

To further assess possible effects of adjustment, it is helpful to consider in more detail those studies which provide 
both adjusted and unadjusted estimates. Lewin et al. [64] saw no effect of snuff before or after adjustment for alcohol and smoking, but did observe a clear dose-response relationship both with alcohol and smoking. Henley et al. [66] found that the non-significant association of oral cancer with smokeless tobacco use seen in never smokers was further reduced after adjustment for alcohol consumption. Perry et al. (Attributable oral cancer risk due to smokeless tobacco use based on a case-control study at Sinai Hospital in Detroit; unpublished) found that additional adjustment for alcohol and smoking reduced risk estimates adjusted only for sex, race, and age from 2.51 to 1.86 and from 1.30 to 0.93 in groups with, respectively lower and higher smokeless tobacco use. Sterling et al. [67] found that a significant sex, race, and age-adjusted association (2.42) in ever as compared to never smokeless tobacco users was virtually eliminated after additional adjustment for alcohol consumption, smoking and occupation. These authors emphasized the strong doseresponse for alcohol consumption (as seen also in other studies considered $[68,69]$ ) as compared to the lack of association for smokeless tobacco use. Although the evidence is limited, the findings are consistent with the notion that confounding by smoking and particularly by alcohol consumption, clearly shown to be a major risk factor in oral cancer [70], is an important consideration.

Unfortunately, the number of estimates adjusted for both smoking and alcohol consumption was rather limited. Overall estimates of the risks associated with chewing tobacco and snuff which can reasonably be compared with each other could therefore be based only on those study-specific estimates (six and seven, respectively) which were adjusted at least for smoking. However, the corresponding estimates of $1.42(0.99-2.03)$ and 1.28 $(0.76-2.14)$ have quite low precision and provide little useful information on whether the associations truly differ. Anyway, they are likely to be biased upward by uncontrolled confounding by alcohol.

For confounding to occur it is necessary for smokeless tobacco users and non-users to differ in their smoking and alcohol consumption. However relevant data seem quite limited and somewhat variable. The evidence seems more consistent for smoking where data indicating a positive relationship with smokeless tobacco use are seen in published studies in the USA $[59,71,72]$ and in Sweden [73] and also in unpublished data provided by Statistics, Sweden (I Sjöberg, personal communication). For alcohol consumption, one study in Sweden [73] and one in the US [43] report a strong association, consistent with the possibility of substantial confounding, but such an association is not clearly evident in other studies. Thus data for men in CPS I and CPS II [66] and from the first National Health and Nutrition Examination Survey [NHANES
I] [41,71] show only a weak association, and, in women, reported alcohol consumption in NHANES I is clearly lower in smokeless tobacco users than in non-smokeless tobacco users, both in smokers and nonsmokers. In a study in North Carolina Winn et al. [13] reported that "most women who dipped snuff did not smoke cigarettes or consume alcoholic beverages," though Nilsson [14] suggested that alcohol consumption may not have been considered proper behaviour for women when the study was conducted, and that this may have led to it being substantially underreported. Whether smokeless tobacco users are more likely to underreport alcohol consumption is unclear.

The importance of confounding by alcohol consumption cannot, however, be fully resolved from the data available. Not only are the available data on the association of alcohol and smokeless tobacco very limited, they are unadjusted for age and race and usually for smoking or sex. Anyway the association may vary by type of smokeless tobacco, type of alcohol, country and period. It certainly seems to us that, at least in some studies, observed differences in risk of oral cancer associated with use of smokeless tobacco and type of tobacco used may be due to confounding by alcohol. In this context it should be noted that other potential sources of confounding are not even mentioned by most authors, like exposure to sunlight (being relevant for lip cancer) which might (as might the use of smokeless tobacco) show a social gradient due to an association with the type of occupation.

Although conclusions based on adjusted estimates seem more convincing than those based on unadjusted ones, they are still not very reliable. One reason is the small number of available estimates. A second reason is the limited nature of the adjustment - thus many of the studies that adjusted for smoking did not take into account amount smoked (e.g. $[13,74,75])$ and one of those that did [68] combined never and light smokers into a single category. Simple adjustment for smoking in broad groups, e.g. never/former/current, may bias risk estimates for smokeless tobacco downwards if in fact smokers who also use smokeless tobacco smoke fewer cigarettes than smokers who do not. The evidence here seems somewhat conflicting, with some studies [73,76] reporting similar cigarette consumption in the two groups, two studies $[77,78]$ reporting somewhat lower consumption in the smokers who also use smokeless tobacco, and one study [41] reporting somewhat higher consumption (here measured by pack-years). Though it would clearly have been better had all studies adjusted for daily cigarette consumption, any bias from this source is likely to be modest. Adjusting for whether or not the subject is a smoker seems to be of more importance. 
A third reason for unreliability of the adjusted estimates is the variability of the findings. As the heterogeneity analysis revealed, study period was a major source, with smaller risks found in more recent studies. In fact, those studies which reported very large relative risk estimates for specific sites $[13,62,63]$ are rather old. Despite methodological limitations, the strength of these site-specific effects indicates that use of oral snuff in the USA at that time was associated with an increased oral cancer risk, especially at locations where the snuff was held. The secular decline in relative risk is encouraging and suggests that even if current use of Western smokeless tobacco poses some risk, it is substantially less than it was decades ago. This decline, and also the decline in US oral cancer rates, may relate to the fact that levels of tobacco-specific nitrosamines [TSNAs] in American smokeless tobacco products, historically much higher than in their Swedish counterparts, have declined by more than 70 percent in the last 25 years $[52,79]$. However we note that there is no definitive evidence linking TSNAs in smokeless tobacco products with oral cancer risk, and that the available data are insufficient to take into account reliably the time lag between smokeless tobacco use and possible development of oral cancer.

Our analyses of smoking adjusted risks seemed to suggest that, compared to non-users, female users of smokeless tobacco might be at higher risk than male users, with fixed-effect relative risks of 2.51 vs 1.15 . The result for females is, however, based on only two studies, of which only the Winn et al. study [13] found an excess risk. Random-effects estimates are similar for women (1.25) and men (1.19), and though one cannot rule out the possibility of an increased effect in women, one cannot infer this from the limited data.

Our analyses showed some indications of publication bias, a finding supported by others [80]. Specific indices of publication bias can also be found in the literature we studied. For example in two studies [32,33] negative results were reported, but no details given.

Our review is consistent with a general trend in appraising the potential risk of oral cancer from use of smokeless tobacco. In the mid 1980s smokeless tobacco was assessed as a risk factor for oral cancer by IARC and the US Surgeon General $[10,11]$. Although, according to an advance report on a forthcoming monograph [81] IARC seems to maintain this view, more recent reviews have reached different conclusions. Whereas tobacco chewing seems to be a major risk factor for oral and pharyngeal cancer in Asia [7] it is now considered unlikely to incur a substantial risk among users of smokeless tobacco products in the United States or Europe (e.g.[82]). The difference in risk between Western smokeless tobacco products and those used in developing countries may be related to tobacco species, fermentation and ageing [83]. Also, the addition of ingredients other than tobacco like betel quid, ash and lime might play a role[12]. For Western tobacco, various reviewers [84-86] have emphasized that any risk of lifethreatening diseases in general that is associated with smokeless tobacco use is very much less than that associated with smoking. For example, Bates et al. [84] conclude that "on average Scandinavian or some American smokeless tobaccos are at least $90 \%$ less hazardous than cigarette smoking."

These reviews have led to discussion as to whether smokeless tobacco might be a less dangerous alternative to smoking for those who do not quit [87-89]. Unlike in the US, tobacco for oral use has been banned in all EU countries, except for Sweden, and a ban also exists in Switzerland. Fagerström and Schildt [90] refer to the low (and declining) prevalence of smoking and the high (and increasing) use of smokeless tobacco in Sweden, and suggest this may be responsible for Sweden having the lowest incidence of tobacco-related disease among developed countries (see [89]). Fagerström and Schildt [90] report that $47 \%$ of current snus users were former smokers and $28 \%$ of ex-smokers used snus at their last attempt to stop smoking. An effect of snus use on smoking cessation was also suggested by Gilljam \& Galanti [91], who found that the proportion of Swedish men that had ever used snus was larger in former than current smokers (55 vs. $45 \%$ ). Discussing whether snus might be a gateway to smoking, Fagerström and Schild [90] report that only $6 \%$ of daily smokers had started tobacco consumption with snus. They concluded that "on balance, there is reason to believe that having snus available to the Swedish population has been of benefit to public health." Whether or not smokeless tobacco use can play a role in helping smokers quit and reducing population risk overall has been fiercely debated in recent years (e.g. $[76,78])$.

\section{Conclusion}

Detailed assessment of the overall risks and benefits of smokeless tobacco use to public health requires consideration of the whole spectrum of its possible health effects and is beyond the scope of this review. While it is clear that there are unique risks from smokeless tobacco use (notably on non-malignant lesions of the oral mucosa [92]), there are numerous reports that support the risks of smoking-related diseases from smokeless tobacco as being generally much less than those from smoking, as was noted above. Although we deliberately refrain from concluding here that smokeless tobacco products represent a lower overall disease risk alternative to cigarettes, we do conclude from our findings that the available data suggest at most a minor increased risk of oral cancer associated with the use of a wide range of currently used Western chewing tobacco and snuff. Observed associations 
may well be due to confounding by smoking or alcohol consumption. Any effect that increasing use of smokeless tobacco use might have at the population level on risk of oral cancer may depend more on the effect such an increase might have on smoking or alcohol consumption than on any direct effect of smokeless tobacco itself.

\section{Competing interests}

ES and RW work for Philip Morris International (PMI), $R \& D$. Both receive their salary from PMI and both own shares in Altria, the holding company of PMI. PNL, founder of P.N. Lee Statistics and Computing Ltd., is an independent consultant in statistics and an advisor in the fields of epidemiology and toxicology to a number of tobacco, pharmaceutical and chemical companies.

\section{Authors' contributions}

PNL conducted an unpublished review and meta-analysis on this subject in 2002. Although RW conducted and wrote up the present analyses, the earlier work provided an extremely helpful basis for comparison and validation at various stages. PNL also assisted with the preparation and layout of the final manuscript for publication. ES initiated the work and made substantial contributions to planning, analysis and writing. He continuously contributed to the work, revised the text critically, and also provided the final language corrections. All authors read and approved the final manuscript.

\section{Acknowledgements}

All costs of this project were covered by Philip Morris International. This is an independent scientific assessment and the views expressed are those of the authors.

We thank Pauline Wassell and Diane Morris for typing the various drafts of this paper, Veronique Riccitelli, Sandra Vaucher and Yvonne Cooper for assistance in obtaining the relevant literature and Grégory Vuillaume for producing the forest plots. We also thank the reviewers for many helpful comments which have considerably improved the paper.

\section{References}

I. World Health Organization: International statistical classification of diseases and related health problems. Tenth revision Volume I. Geneva: WHO; 1992.

2. International Agency for Research on Cancer: Globocan 2002 database project 2002 [http://www-dep.iarc.fr/].

3. American Cancer Society: All about oral cavity and oropharyngeal cancer 2005

[http://www.cancer.org/docroot/CRI/CRI 2x.asp?sitearea $=\& d t=60$ ].

4. World Health Organization: WHO statistical information system (WHOSIS) 2005 [http://www.who.int/whosis].

5. Scully C, Bedi R: Ethnicity and oral cancer. Lancet Oncol 2000, I:37-42.

6. Rodu B, Cole P: Tobacco-related mortality [Letter]. Nature 1994, 370:184.

7. Stratton K, Shetty P, Wallace R, Bondurant S, (Eds): Clearing the smoke. In Assessing the science base for tobacco harm reduction Washington, DC: National Academy Press; 2001.

8. Wahlberg I, Ringberger T: Smokeless tobacco. In Tobacco: production, chemistry, and technology Edited by: Davis DEL, Nielsen MR. Oxford: Blackwell Science Ltd; 1999:452-460.

9. Pershagen G: Smokeless tobacco. Br Med Bull I 996, 52:50-57.
10. International Agency for Research on Cancer: Tobacco habits other than smoking; betel-quid and areca-nut chewing; and some related nitrosamines Volume 37. Lyon, France: IARC; 1985. [IARC Monographs on the evaluation of the carcinogenic risk of chemicals to humans.]

II. US Surgeon General: The health consequences of using smokeless tobacco. A report of the Advisory Committee to the Surgeon General, 1986. Bethesda, Maryland: US Department of Health and Human Services; Public Health Service; 1986. NIH Publication No. 86-2874 [http://www.cdc.gov/tobacco/sgr/index.htm].

12. Gross AJ, Lackland DT, Tu DS: Oral cancer and smokeless tobacco: literature review and meta-analysis. Environ Int 1995, 2 I:381-394.

13. Winn DM, Blot WJ, Shy CM, Pickle LW, Toledo A, Fraumeni JF Jr: Snuff dipping and oral cancer among women in the southern United States. N Engl J Med I 98I, 304:745-749.

14. Nilsson R: A qualitative and quantitative risk assessment of snuff dipping. Regul Toxicol Pharmacol 1998, 28: I- I6.

15. Bouquot JE, Meckstroth RL: Oral cancer in a tobacco-chewing US population - no apparent increased incidence or mortality. Oral Surg Oral Med Oral Pathol 1998, 86:697-706.

16. Rodu B, Cole P: Smokeless tobacco use and cancer of the upper respiratory tract. Oral Surg Oral Med Oral Pathol Oral Radiol Endod 2002, 93:5। I-5I5.

17. Critchley JA, Unal B: Health effects associated with smokeless tobacco: a systematic review. Thorax 2003, 58:435-443.

18. Fleiss JL, Gross AJ: Meta-analysis in epidemiology, with special reference to studies of the association between exposure to environmental tobacco smoke and lung cancer: a critique. J Clin Epidemiol 1991, 44:127-139.

19. Greenland S, Longnecker MP: Methods for trend estimation from summarized dose-response data, with applications to meta-analysis. Am J Epidemiol 1992, I35: I301-I309.

20. Fry JS, Lee PN: Revisiting the association between environmental tobacco smoke exposure and lung cancer risk. I. The dose-response relationship with amount and duration of smoking by the husband. Indoor + Built Environment 2000, 9:303-316.

21. Hamling JS, Lee PN, Weitkunat R, Ambühl M: Facilitating metaanalyses by deriving relative effect and precision estimates for alternative comparisons from a set of estimates presented by exposure level or disease category. Stat Med 2007.

22. Armitage P, Berry G: Statistical methods in medical research 3rd edition. Oxford: Blackwell Publishing; 1994.

23. Higgins JPT, Thompson SG, Deeks JJ, Altman DG: Measuring inconsistency in meta-analyses. BMJ 2003, 327:557-560.

24. Deeks JJ, Altman DG, Bradburn MJ: Statistical methods for examining heterogeneity and combining results from several studies in meta-analysis. In Systematic reviews in health care: metaanalysis in context 2 nd edition. Edited by: Egger M, Davey Smith G, Altman DG. London: BMJ Books; 2001:285-312.

25. Light RJ, Pillemer DB: Summing up: the science of reviewing research Cambridge, Massachusetts: Harvard University Press; 1984.

26. Egger M, Davey Smith G, Schneider M, Minder C: Bias in metaanalysis detected by a simple, graphical test. BMJ 1997 , 3 1 5:629-634.

27. Wynder EL, Hultberg S, Jacobsson F, Bross IJ: Environmental factors in cancer of the upper alimentary tract. A Swedish study with special reference to Plummer-Vinson (Paterson-Kelly) syndrome. Cancer 1957, 10:470-487.

28. Smith JF, Mincer HA, Hopkins KP, Bell J: Snuff-dipper's lesion: a cytological and pathological study in a large population. Arch Otolaryngol 1970, 92:450-456.

29. Smith JF: Snuff dippers lesion: a ten-year follow-up. Arch Otolaryngol 1975, 10 I:276-277.

30. Bjelke E, Schuman LM: Chewing of tobacco and use of snuff: relationships to cancer of the pancreas and other sites in two prospective studies. Proceedings of the 13th International Congress on Cancer, Seattle, Washington 1982:207.

31. Winn DM, Blot WJ, Shy CM, Fraumeni JF Jr: Occupation and oral cancer among women in the South. Am J Ind Med 1982, 3:161-167.

32. Young TB, Ford CN, Brandenburg JH: An epidemiologic study of oral cancer in a statewide network. Am J Otolaryngol 1986, 7:200-208. 
33. Spitz MR, Fueger J, Halabi S, Schantz SP, Sample D, Hsu TC: Mutagen sensitivity in upper aerodigestive tract cancer: a casecontrol analysis. Cancer Epidemiol Biomarkers Prev 1993, 2:329-333.

34. Bouquot JE: Oral verrucous carcinoma: incidence in two US populations. Oral Surg Oral Med Oral Pathol Oral RadiolEndod 1998, 86:318-324.

35. Schlecht NF, Franco EL, Pintos J, Negassa A, Kowalski LP, Oliveira BV, Curado MP: Interaction between tobacco and alcohol consumption and the risk of cancers of the upper aero-digestive tract in Brazil. Am J Epidemiol 2000, I 50: I I 29- I I 37.

36. Axéll T, Mörnstad H, Sundström B: Snusning och munhalecancer: en retrospektiv studie. (Snuff taking and oral cancer: a retrospective study). Tandläkartidningen 1978, 70:1048-1052.

37. Sundström B, Mörnstad H, Axell T: Oral carcinomasassociated with snuff dipping. Some clinical and histological characteristics of $\mathbf{2 3}$ tumours in Swedish males. Journal of Oral Pathology 1982, I I:245-25I.

38. McGuirt WF: Snuff dipper's carcinoma. Arch Otolaryngol 1983, I 09:757-760.

39. Link MJO, Kaugars GE, Burns JC: Comparison of oral carcinomas in smokeless tobacco users and nonusers. J Oral Maxillofac Surg 1992, 50:452-455.

40. Wray A, McGuirt WF: Smokeless tobacco usage associated with oral carcinoma: incidence, treatment, outcome. Arch Otolaryngol Head Neck Surg 1993, I I 9:929-933.

4I. Accortt NA, Waterbor JW, Beall C, Howard G: Chronic disease mortality in a cohort of smokeless tobacco users. Am J Epidemiol 2002, I 56:730-737.

42. Bundgaard T, Wildt J, Bjerrum P, Elbrønd O: Case-control epidemiology of cancer cavi oris: preliminary results. Acta Otolaryn gol 1988, 449:209-2। I.

43. Kaugars GE, Brandt RB, Chan W, Carcaise-Edinboro P: Evaluation of risk factors in smokeless tobacco-associated oral lesions. Oral Surg Oral Med Oral Pathol I99I, 72:326-331.

44. Fabian MC, Irish JC, Brown DH, Liu TC, Gullane PJ: Tobacco, alcohol, and oral cancer: the patient's perspective. I Otolaryngol 1996, 25:88-93.

45. Odenbro Å, Bellocco R, Boffetta P, Lindelöf B, Adami J: Tobacco smoking, snuff dipping and the risk of cutaneous squamous cell carcinoma: a nationwide cohort study in Sweden. $\mathrm{Br} J$ Cancer 2005, 92:1326-1328.

46. Notani PN, Jayant K: Role of diet in upper aerodigestive tract cancers. Nutr Cancer 1987, 10:103-1 I3.

47. Al-Rajhi N, Khafaga Y, El-Husseiny J, Saleem M, Mourad W, Al-Otieschan A, Al-Amro A: Early stage carcinoma of oral tongue: prognostic factors for local control and survival. Oral Oncol 2000, 36:508-5।4.

48. El-Husseiny G, Kandil A, Jamshed A, Khafaga Y, Saldem M, Allam A, Al-Rajhi N, Al-Amro A, Rostom AY, Abuzeid M, Otieschan A, Flores $A$ : Squamous cell carcinoma of the oral tongue: an analysis of prognostic factors. Br J Oral Maxillofac Surg 2000, 38:193-199.

49. Haidinger $\mathrm{G}$, Hollestein U: Dose dependant relative risk for oral cancer in tobacco chewers [Letter]. Eur J Epidemiol 1991, 7:93-94

50. Ebbert JO, Yang P, Tomar SL: Re: "Chronic disease mortality in a cohort of smokeless tobacco users" [Letter]. Am J Epidemiol 2003, I 58: I02I.

51. Winn DM, Pickle LW: Smokeless tobacco and cancer in women: implications for cancer research. Women Health 1986 I I:253-266.

52. Rodu B, Jansson C: Smokeless tobacco and oral cancer: a review of the risks and determinants. Crit Rev Oral Biol Med 2004, I 5:252-263.

53. Moore GE, Bissinger LL, Proehl EC: Tobacco and intra-oral cancer. Surg Forum 1952, 3:685-688.

54. Wynder EL, Bross IJ, Feldman RM: A study of the etiological factors in cancer of the mouth. Cancer 1957, 10:1300-1323.

55. Blot WJ, Winn DM, Fraumeni JF Jr: Oral cancer and mouthwash. J Natl Cancer Inst 1983, 70:25 I-253.

56. Muscat JE, Richie JP Jr, Thompson S, Wynder EL: Gender differences in smoking and risk for oral cancer. Cancer Res 1996, 56:5192-5197.

57. Moore GE, Bissinger LL, Proehl EC: Intraoral cancer and the use of chewing tobacco. J Am Geriatr Soc 1953, 1:497-506.

58. Wynder EL, Bross I]: Aetiological factors in mouth cancer: an approach to its prevention. $\mathrm{Br}$ Med J 1957, I 8: I I37-II43.
59. Kabat GC, Chang CJ, Wynder EL: The role of tobacco, alcohol use, and body mass index in oral and pharyngeal cancer. Int J Epidemiol 1994, 23: I | 37- I |44.

60. Lee PN: Oral cancer and smokeless tobacco. A review of the epidemiological evidence relating to western populations 2002 [http://www.pnlee.co.uk/reflist.htm]. Sutton, Surrey: P N Lee Statistics and Computing Ltd [Download LEE2002N]

61. Döbróssy L: Epidemiology of head and neck cancer: magnitude of the problem. Cancer Metastasis Rev 2005, 24:9-I7.

62. Vogler WR, Lloyd JW, Milmore BK: A retrospective study of etiological factors in cancer of the mouth, pharynx, and larynx. Cancer 1962, I 5:246-258.

63. Westbrook KC, Suen JY, Hawkins JM, McKinney DC: Snuff dipper's carcinoma: Fact or fiction? In In Prevention and Detection of Cancer Edited by: Nieburg HE. New York: Marcel Dekker; I980: I367- I37I.

64. Lewin F, Norell SE, Johansson H, Gustavsson P, Wennerberg J, Biörklund A, Rutqvist LE: Smoking tobacco, oral snuff, and alcohol in the etiology of squamous cell carcinoma of the head and neck: a population-based case-referent study in Sweden. Cancer 1998, 82: | 367-1375.

65. Stockwell HG, Lyman GH: Impact of smoking and smokeless tobacco on the risk of cancer of the head and neck. Head Neck Surg 1986, 9: 104-1 I0.

66. Henley SJ, Thun MJ, Connell C, Calle EE: Two large prospective studies of mortality among men who use snuff or chewing tobacco (United States). Cancer Causes Control 2005, I 6:347-358.

67. Sterling TD, Rosenbaum WL, Weinkam JJ: Analysis of the relationship between smokeless tobacco and cancer based on data from the national mortality followback survey. J Clin Epidemiol |992, 43:223-23|.

68. Mashberg A, Boffetta P, Winkelman R, Garfinkel L: Tobacco smoking, alcohol drinking, and cancer of the oral cavity and oropharynx among U.S. veterans. Cancer 1993, 72: I369-| 375.

69. Schwartz SM, Daling JR, Doody DR, Wipf GC, Carter J, Madeleine MM, Mao E-J, Fitzgibbons ED, Huang S, Beckmann AM, McDougall JK, Galloway DA: Oral cancer risk in relation to sexual history and evidence of human papillomavirus infection. J Natl Cancer Inst 1998, 90:1626-1636.

70. Ogden GR: Alcohol and oral cancer. Alcohol 2005, 35:169-I73.

7I. Accortt NA, Waterbor JW, Beall C, Howard G: Cancer incidence among a cohort of smokeless tobacco users (United States). Cancer Causes Control 2005, 16: I I07-III5.

72. Zahm SH, Heineman EF, Vaught JB: Soft tissue sarcoma and tobacco use: data from a prospective cohort study of United States veterans. Cancer Causes Control 1992, 3:37I-376.

73. Schildt E-B, Eriksson M, Hardell L, Magnuson A: Oral snuff, smoking habits and alcohol consumption in relation to oral cancer in a Swedish case-control study. Int / Cancer 1998, 77:34|-346.

74. Broders AC: Squamous-cell epithelioma of the lip. A study of five hundred and thirty-seven cases. JAMA 1920, 74:656-664.

75. Keller AZ: Cellular types, survival, race, nativity, occupations, habits and associated diseases in the pathogenesis of lip cancers. Am J Epidemiol 1970, 9 1:486-499.

76. Haddock CK, Weg MV, Debon M, Klesges RC, Talcott GW, Lando $H$, Peterson A: Evidence that smokeless tobacco use is a gateway for smoking initiation in young adult males. Prev Med 200I, 32:262-267.

77. Wetter DW, McClure JB, de Moor C, Cofta-Gunn L, Cummings S, Cinciripini PM, Gritz ER: Concomitant use of cigarettes and smokeless tobacco: prevalence, correlates, and predictors of tobacco cessation. Prev Med 2002, 34:638-648.

78. Hatsukami DK, Lemmonds C, Tomar SL: Smokeless tobacco use: harm reduction or induction approach? Prev Med 2004, 38:309-317.

79. Hoffmann D, Djordjevic MV, Fan J, Zang E, Glynn T, Connolly GN: Five leading U.S. commercial brands of moist snuff in 1994: assessment of carcinogenic $\mathbf{N}$-nitrosamines. J Natl Cancer Inst 1995, 87: 1862-1869.

80. Waterbor JW, Adams RM, Robinson J, Crabtree FG, Accortt NA, Gilliland J: Disparities between public health educational materials and the scientific evidence that smokeless tobacco use causes cancer. J Cancer Educ 2004, 19:17-28.

8I. Cogliano V, Straif K, Baan R, Grosse Y, Secretan B, El Ghissassi F: Smokeless tobacco and tobacco-related nitrosamines. Lancet Oncol 2004, 5:708. 
82. Boffetta P, Aagnes B, Weiderpass E, Andersen A: Smokeless tobacco use and risk of cancer of the pancreas and other organs. Int J Cancer 2005, I | 4:992-995.

83. Idris AM, Ibrahim YE, Warnakulasuriya KAAS, Cooper DJ, Johnson NW, Nilsen R: Toombak use and cigarette smoking in the Sudan: estimates of prevalence in the Nile state. Prev Med 1998, 27:597-603.

84. Bates C, Fagerström K, Jarvis MJ, Kunze M, McNeill A, Ramström L: European Union policy on smokeless tobacco: a statement in favour of evidence based regulation for public health. Tob Control 2003, 1 2:360-367.

85. Royal College of Physicians (Ed): Protecting smokers, saving lives: the case for a tobacco and nicotine regulatory authority 2002 [http:// www.rcplondon.ac.uk/pubs/books/protsmokers/ProtSmokers.pdf]. London: Royal College of Physicians

86. Levy DT, Mumford EA, Cummings KM, Gilpin EA, Giovino G, Hyland $A$, Sweanor D, Warner KE: The relative risks of a low-nitrosamine smokeless tobacco product compared with smoking cigarettes: estimates of a panel of experts. Cancer Epidemiol Biomarkers Prev 2004, I 3:2035-2042.

87. Russell MAH, Jarvis MJ, Feyerabend C: A new age for snuff? Lancet I980, I:474-475.

88. Rodu B: How smokeless tobacco can save your life New York: Sulzberger \& Graham; 1995.

89. Jiménez-Ruiz C, Kunze M, Fagerström KO: Nicotine replacement: a new approach to reducing tobacco-related harm. Eur Respir J 1998, I I:473-479.

90. Fagerström KO, Schildt EB: Should the European Union lift the ban on snus? Evidence from the Swedish experience. Addiction 2003, 98: II91-II95.

91. Gilljam H, Galanti MR: Role of snus (oral moist snuff) in smoking cessation and smoking reduction in Sweden. Addiction 2003, 98: I I83-I I89.

92. Shulman JD, Beach MM, Rivera-Hidalgo F: The prevalence of oral mucosal lesions in US adults: data from the Third National Health and Nutrition Examination Survey, I 988-1994. J Am Dent Assoc 2004, I35: | 279- 286.

93. Peacock EE Jr, Greenberg BG, Brawley BW: The effect of snuff and tobacco on the production of oral carcinoma: An experimental and epidemiological study. Ann Surg 1960, I 5 I:542-550.

94. Vincent RG, Marchetta F: The relationship of the use of tobacco and alcohol to cancer of the oral cavity, pharynx or larynx. Am J Surg 1963, 106:501-505.

95. Martínez I: Factors associated with cancer of the esophagus, mouth, and pharynx in Puerto Rico. I Natl Cancer Inst 1969, 42:1069-1094.

96. Browne RM, Camsey MC, Waterhouse JAH, Manning GL: Etiological factors in oral squamous cell carcinoma. Community Dent Oral Epidemiol 1977, 5:301-306.

97. Williams RR, Horm JW: Association of cancer sites with tobacco and alcohol consumption and socioeconomic status of patients: interview study from the Third National Cancer Survey. J Natl Cancer Inst 1977, 58:525-547.

98. Wynder EL, Stellman SD: Comparative epidemiology of tobacco-related cancers. Cancer Res 1977, 37:4608-4622.

99. Wynder EL, Kabat G, Rosenberg S, Levenstein M: Oral cancer and mouthwash use. J Natl Cancer Inst 1983, 70:255-260.

100. Blot WJ, McLaughlin JK, Winn DM, Austin DF, Greenberg RS, Preston-Martin S, Bernstein L, Schoenberg JB, Stemhagen A, Fraumeni JF $\mathrm{Jr}$ : Smoking and drinking in relation to oral and pharyngeal cancer. Cancer Res 1988, 48:3282-3287.

I0I. Spitz MR, Fueger JJ, Goepfert H, Hong WK, Newell GR: Squamous cell carcinoma of the upper aerodigestive tract: a case comparison analysis. Cancer 1988, 61:203-208.

102. Franco EL, Kowalski LP, Oliveira BV, Curado MP, Pereira RN, Silva $\mathrm{ME}$, Fava AS, Torloni H: Risk factors for oral cancer in Brazil: A case-control study. Int / Cancer 1989, 43:992-1000.

103. Blomqvist G, Hirsch J-M, Alberius P: Association between development of lower lip cancer and tobacco habits. J Oral Maxillofac Surg 1991, 49: 1044-1047.

104. Maden C, Beckmann AM, Thomas DB, McKnight B, Sherman KJ, Ashley RL, Corey L, Daling JR: Human papillomaviruses, herpes simplex viruses, and the risk of oral cancer in men. Am J Epidemiol 1992, 135:1093-1102.
105. Bundgaard T, Wildt J, Frydenberg M, Elbrønd O, Nielsen JE: Casecontrol study of squamous cell cancer of the oral cavity in Denmark. Cancer Causes Control 1995, 6:57-67.

106. Muscat JE, Wynder EL: A case/control study of risk factors for major salivary gland cancer. Otolaryngol Head Neck Surg 1998, I I8:195-198.

\section{Pre-publication history}

The pre-publication history for this paper can be accessed here:

http://www.biomedcentral.com/1471-2458/7/334/pre pub
Publish with Bio Med Central and every scientist can read your work free of charge

"BioMed Central will be the most significant development for disseminating the results of biomedical research in our lifetime. " Sir Paul Nurse, Cancer Research UK

Your research papers will be:

- available free of charge to the entire biomedical community

- peer reviewed and published immediately upon acceptance

- cited in PubMed and archived on PubMed Central

- yours - you keep the copyright

Submit your manuscript here:

http://www.biomedcentral.com/info/publishing_adv.asp
BiolMedcentral 